ESTABLISHED IN 1783.

$\boldsymbol{\Lambda}$

PRICED AND ILLUSTRATED

CATALOGUE

or

\title{
MATHEMATICAL INSTRUMENTS,
}

OF GERMAN SILVER AND BRASS,

\section{SWISS DRAWING INSTRUIIENTS,}

TRANSITS, LEVELS, SURVEYING COMPASSES, TAPE MEASURES,

CHAINS, SCALES, \&C, dCo,

AND AII SUPPIIES FOR

Engineers, Architects, Surveyors and Machinists.

PATTICUTAR ATTENTION IS CALTED TO THE

SWISS DRAWING INSTRUMENTS.

This Catalogue is furntshed Gratis, and will be sent free by rail, to any part of the United States, Canada, West Indies and South Ameriea.

DMPORTED AND MANUFACTURED. And Sold Wholesale and Retail by

\section{WILLIAM Y. MALListeR, OPTICIAN,}

728 CHESTNUT STREET,

PHILADELPHIA, PA.

September, 1867.

P H I I A D E L P H I A :

JAS. B. RODGERS, PRINTER, 52 \& 54 NORTa SIXTH STREet.

1867. 


\section{CONTENTS.}

- Alteneiler's Instruments, ..........................12

Bull und Socketa, ,...................................3t

Beam Compuss, ,....................................t,12

Beam Compass Furnituré,.................12,14,19

Books,

$5,12,14,15,19$

Bow Pens,

$5,12,14,15,19$

Bow Pencils, ..

$.12,14$

Boxwood Doams,

125

Boxwood Scales, .........................

Calipers,

30

Caliper Rnles,

30

Calipur Squares,

(30)

Camels Ilair Penclls,

Caves of Instrumentw, $\$$ wiss, ......................7,8

" " Ger. Sllver,....15,16,17,19

$\therefore \quad$ a Brass...............20,21,22

Ceutre Gnuges, .......................................4t

Compazses, Surveyors,..............................33

" I'ocket,...............................3\$,39

Clynoweter Rules,...................................32

Curves, Horn, ....................................6,29

" Wood,........................................29

Dividers, in Seta,...........................3,12,13,18

i: $\quad 11$ wir Springr,...................3,12,13,18

، Pluin,............................4,12,13,15

6. Blatcting,.............................. 4,14

4 Pocket, .................................4,13

$4 \quad$ Proportlonal, ....................4,12,14,19

". Threo Legged,.........................4,13

" Eniversal,.............................5, 14

tf Spacing,......................6,12,I 1,15

Drawing Pons,................................5,15,19

" $"$ double,............................,6,15

Drawing Büards, ......................................29

Frasing Knives,......................................42

Horn Centre,.......................................6,15

Irory Scales, ........................................25

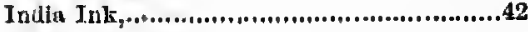

India Rubber, ......................................42

Jacob Staff, ............................................3t

Level, Engineers, ................................35

\& Bragt, .........................................35

"4 Bullit, ,..........................................35

" Slope,..........................................36

w Lockes Hand,.................................36

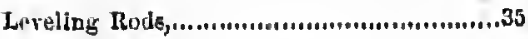

Lesd Poncll , ...........................................4t

Lithograph Pens,........................................t.

Magnifying Glataw, ,.................................t5

Map Porumbulatorn, ................................. 1.

Mlarking Ping, .........................................34

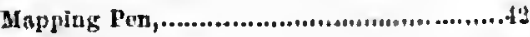

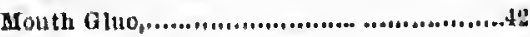

Oduntographts, ........................................tt

Paint Slabs und Saucors,.........................48

Paper, Drawing, ..................................42, 43

" Pattorn,.....................................43

* Proflle,.......................................43

4 Trucing,......................................43

، Pius,......................................6,1 15, 10

" Scnle日,.........................................20

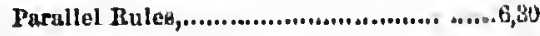

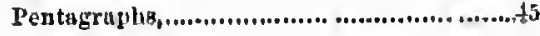

Plumb Bobe, ..........................................tet

Polar Planimeter, .........................9,10,11

Protractors, Brass, ,........... ....................... $\$ 2$

" Bevel, ................................2t

« Irory, $, \ldots \ldots \ldots \ldots \ldots \ldots \ldots \ldots \ldots . . . \ldots 4,25$

"1 Horn, ................................22

" German Silver,...........13,22,23,24

" Puper,.....................................24

" Swisa,...............................6,2t

Rovlette, or Dotting Pen,......................6,15

Rules, Excentrlo,.................................t

* Parallel,.................................6, 60

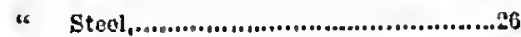

Snble ITnir Pencils, .................................t2

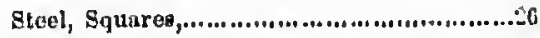

“ Struight odge\&,..................................28

Squares, German Silver,.............................

Surveying Chains, ,..... ...........................st

Swi木s Instrument $, 0 . \ldots \ldots \ldots \ldots \ldots \ldots \ldots \ldots \ldots, 4,6,6,7,8$

IE Squares, ........................................83

Tape Heasures, .................... ...............37, 33

Trankits,........................................34

Triangles,.........................................29

Tripods, ..............................................st

Univerenl Bquares,...............................27

Vornter Calipers, .....................................31

Water Colors,...................................40,41

Wire Gauges, ,........................................tt 


\section{Suiss 翼rawing 近struments.}

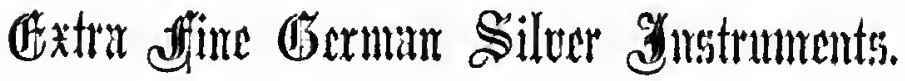

IIaving purchased from Mr. Amsler, who has retired from business, his interest in, and stock of, these celebrated Instruments, for which he was the principal agent, I am able to offer them on the most favorable terms.

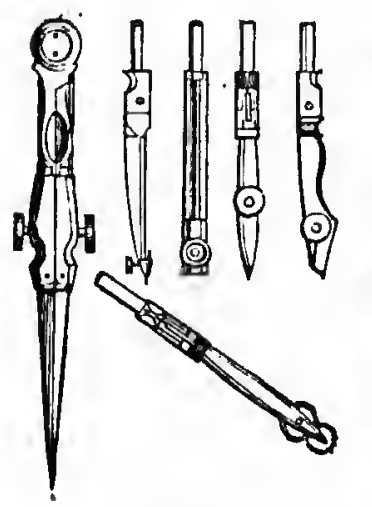

3000

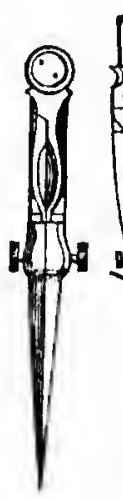

3001

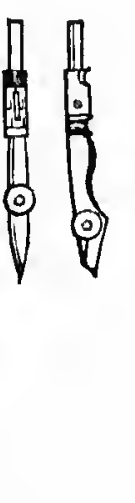

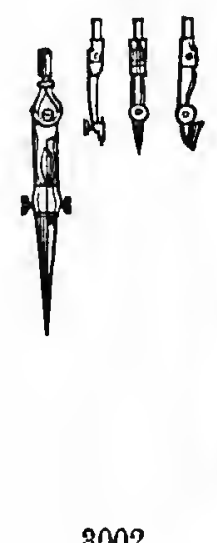

3002

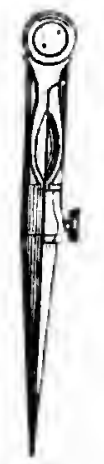

3003

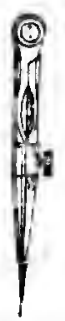

No. 3000. Dividers, $6 \frac{1}{2}$ inches long, with joints in each leg, with pen, pencil- Price. 3001. Dividers, 6 inches long, with pen, pencil-holder, needle-point, and lengthening bar,................................... 3002. Dividers, 4 inches long, with pen, pencil-holder, and necdle-point,

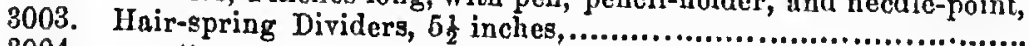
3004 . "sing Dividers, ${ }_{41}^{2}$ " 


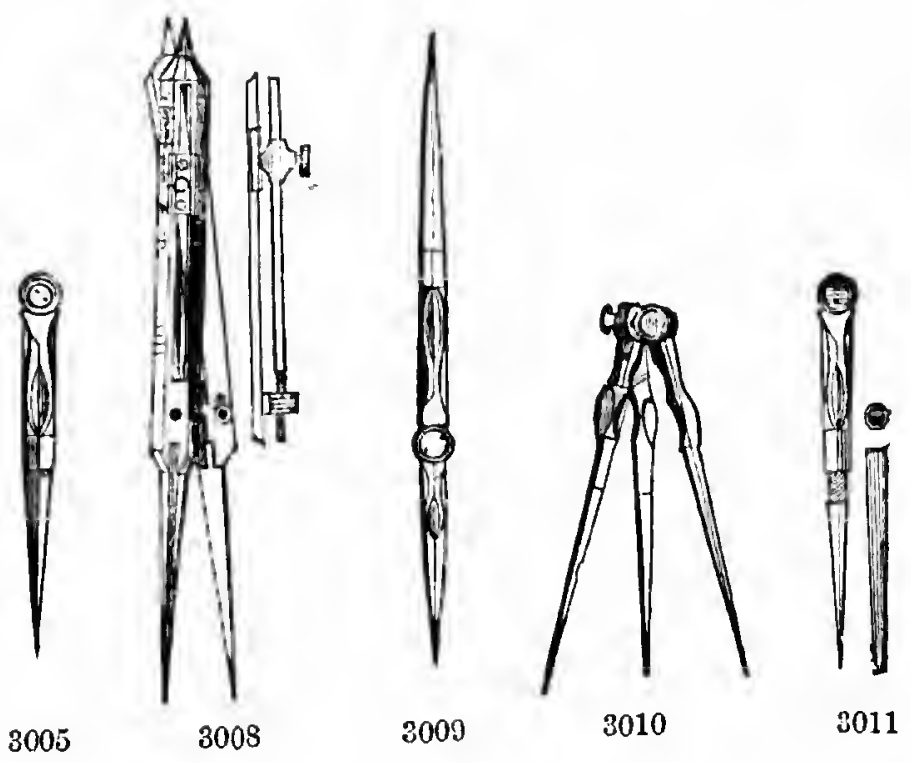

No.

Price.

3005. Plain Dividers,

8006. "* " 3007 . Proportional Dividers, with Rack, fincly gradunted, for lines and circles, 9 inches long,............................................

3008. Iroportional Dividers, with Micrometer adjustment, fincly graluated for lines and circles, 9 inclies long,..........................

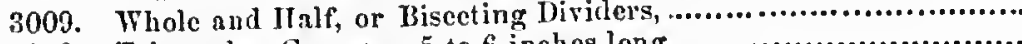

3010. Triangular Compass, 5 to 6 inches long,.............................

3011. Pocket Dividers, with Shenth,
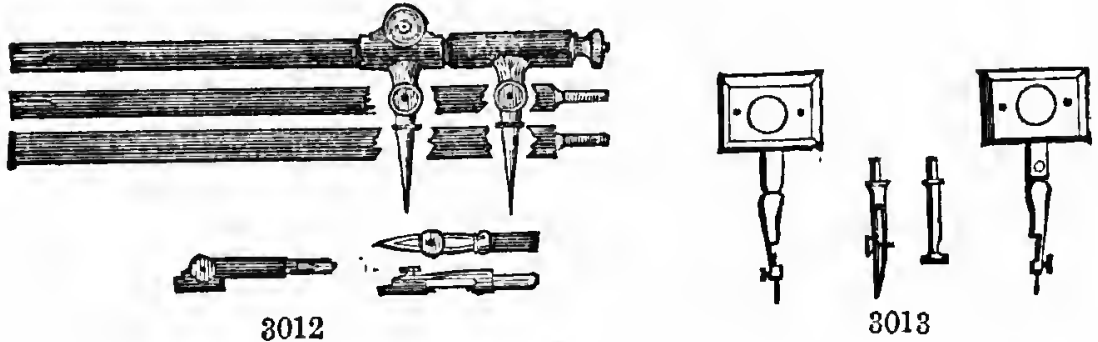

3012. Beam Compass, 24 inches long, in 3 German Silver bars, with pen, pencil, ncedle-point, and two strnight points, Micrometer

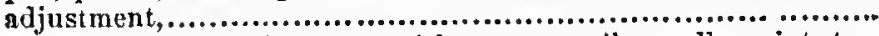

Furniture for Beam Compass, with pen, pencil, necdle-point, two straight points, Micrometer adjustment. 


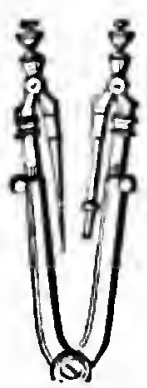

3014

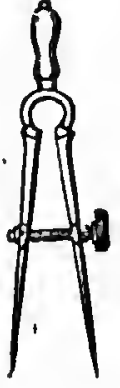

3015

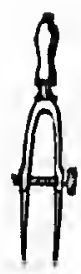

3016

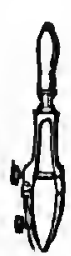

3017

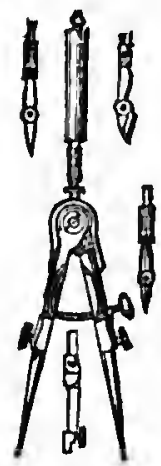

3021

No,

3014. Universal, or Pillar Compasses, with handles-a very useful instrument,

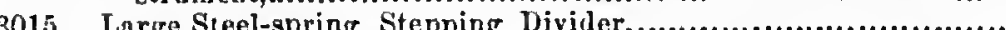

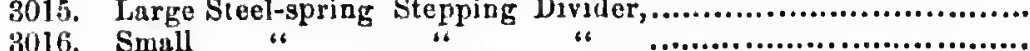

3017. " " " Bow Pen,........................................

3018 " "

3019. "

" " with needle-point,

"6

Pencil,....

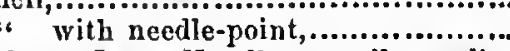

3020. Spring Bow Pen, 4 inches long, Irory Handle, peneil, needle-

3021. Spring Bow Pen, 4 inches
point, 2 pen points-in fact, a complete set of instruments,.....

Price.

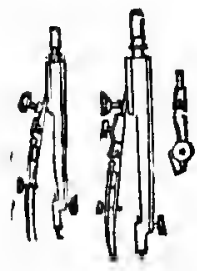

3022

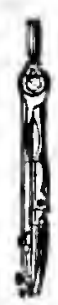

8024
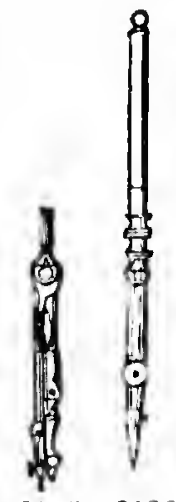

3025

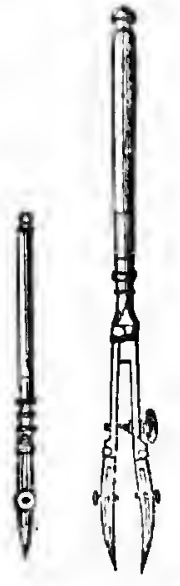

3028
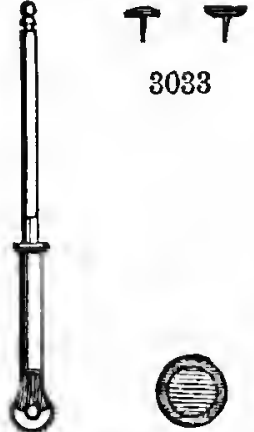

3032

3022. Spring Bow Pen, German Silver, with needle-point,................ 3023. " " " " and pencil-point, 3024. Bow Compass, German Silver, with needle-point, and pen, joints in each leg, ........................................................ 3025. Bow Compass, German Silver, with needle-point, and pencil-holder joints in each leg, .......................................................

3026. Drawing Pen, 6 inches long, with joints,.......................... 3027. 3028.

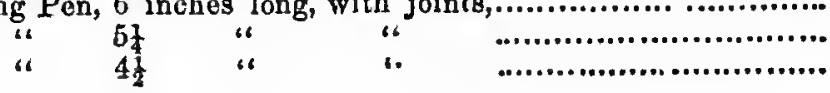


No.

3029. Rail Road, or Doublo Draising I

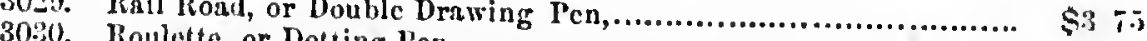

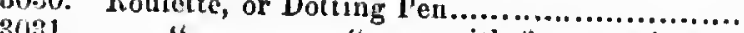

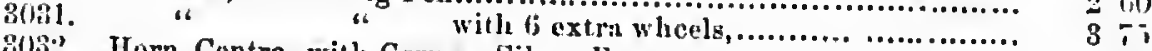

Bus:2. Irorn Centre, with German Silver Frame,.......................... 40

80:33. German Silver Paper Pins, or Thumb Tacks,............... per doz. 303:iz. Stecl is

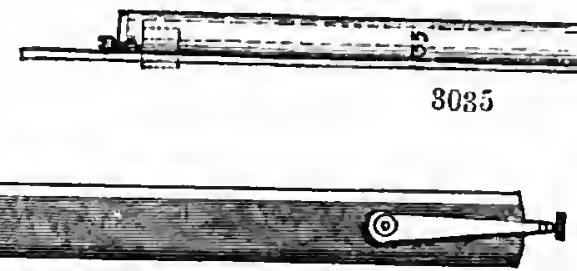

3024
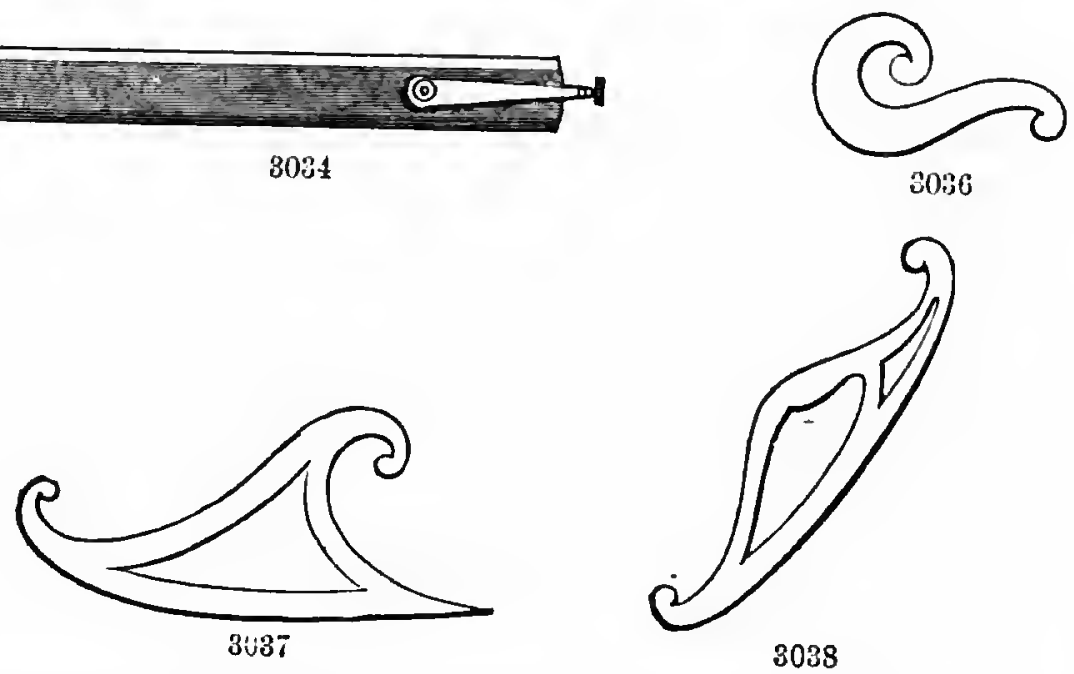

s0:36

3034. Eccentric Rule, Ebony, Gcrman Silver Mounting, 12 inchesvery useful for drawing Bevel Gear, Paddles, \&c.,...............

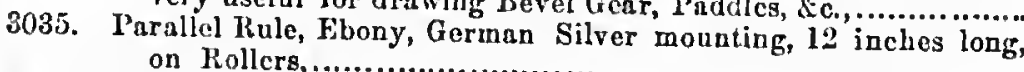

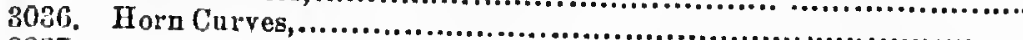

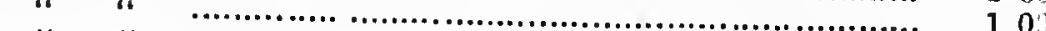

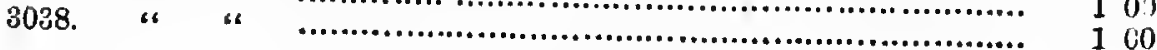

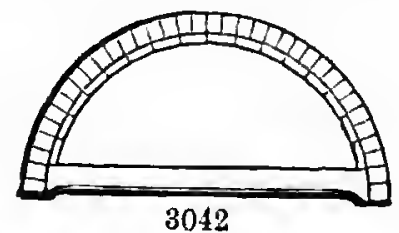

3039. German Silver Protractor, $\frac{1}{2}$ circle, $\frac{1}{2}$ degrees, 41 in. outside centre, $\quad 185$

3910.

8041 .

3012.

3043 .

“

$\begin{array}{lll}\frac{1}{2} & \text { “ } & \frac{1}{2} \\ \frac{1}{2} & \text { “ } & \frac{1}{4} \\ \frac{1}{2} & \text { “ } & \frac{1}{2} \\ \frac{1}{2} & \text { c } & \frac{4}{4}\end{array}$

“6

53

6

$5^{2}$ in. inside centre,

260

400

275

Persons wishing to get up a cose of instruments, can select the ents, can select the pieces from the to $\$ \cup 0$, and I can have boxes made for them, at an additional cost of from $\$ 5$ Rosewood, and lined to size and finish. The Boxes are made of Walnut or 


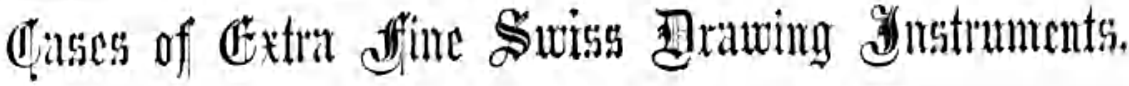

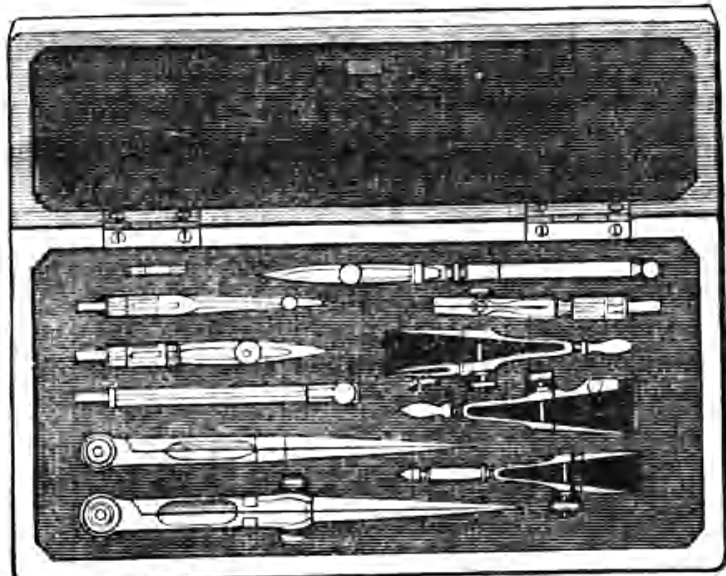

3050

3050. Polished Walnut Box, containing:-

Pair Dividers, 6 inches long, pen, pencil, needle-point and lengthening bar;

Pair Plain Dividers, 51 inches long;

Pair Steel Spaciug Dividers;

Steel Bow Pen;

$$
\text { " Pencil; }
$$

Drnwing Pen, 51 inches long;

Half Circle Protractor, 41 inch, $\frac{1}{2}$ degrees......................

2051. Polished Rosewood Box, with Tray, Lock and Key, containing:-
Pair Dividers, 6 inches long, with pen, pencil, needle-point, and lengthening bar;

Pair Plain Dividers, $5 \frac{1}{2}$ inches long;

Pair Dividers, 32 inches long, with pen, pencil ant needle-point;

Pair Steel Spacing Dividers;

Steel Bow Pen;

Steel bow Pencil;

One Drawing Pen, 6 inches long;

$$
\text { " } 4 \frac{1}{2} \text { " }
$$

Half Circle Protractor, German Silver, $\frac{1}{2}$ degrees, 43 inches;

Boxwood Triangular Seale, 12 inches long,......................

3052. Polished Rosewood Box, with Tray, Lock and Key, containing:-

Pair Dividers, 61 inches long, with pen, peneil, needle-point, dotter, and lengthening bar;

Pair IIair Spring Dividers, $5 \frac{1}{2}$ inches long;

Pair Proportional Dividers, with Rack;

Spring Bow Pen, with Ivory Handle, pencil, needle-point, and two pen points;

Furniture for Wood Beam Compass;

One Drawing Pen, 6 inch;

$$
\text { " } 451
$$

IInlf Circle Protractor, 5.1 inch, $\frac{1}{4}$ degrees, inside centre;

Boxwond Triangular Scale, 12 inches long;

6 Paints, India Ink, Paint Slabs, \&e., 
No.

3053. Polished Rosewood Box, with Tray, Loek and Key, oontaining:-

Pair Dividers, $6 \frac{1}{2}$ inches long, with pen, peneil, needle-point, dotter, and lengthening bar;

Pair Dividers, 4 inebes long, with pen, pencil and needle-point;

Pair Hair Spring Dividers, $6 \frac{1}{2}$ inehes long;

Pair Plain Dividers, $5 \frac{1}{2}$ " 6

Spring Bow Pen, with Irory Handle, Micrometer adjustment, pencil, needle-point, and two pen points;

Pair Proportional Dividers, 9 inches long, with Miorometer adjustment;

Steel Spaeing Dividers;

a Bow Pcn;

" "Pencil;

German Silver Bow Pen, with pencil leg;

Rail Road Drawing Pen;

Dotting Pen, with extra wheels;

Three Drawing Pens, one each $4 \frac{1}{2}$ ineh, $6+$ ineh, and 6 ineh;

Red Ink Drawing Pen;

Beam Compass, in 3 Bars, 24 inches long;

Half Circle Protraetor, with arm and vernier, 8 inch, reads to minutes;

Ebony Rolling Parallel Rule;

" Eeeentrie Rule;

2 Boxwood Triangular Scales, 12 inches long - 10ths and 12ths ;

Ink Slab and 6 color cups; 12 Paints and India Ink,.............. $\$ 13000$

The abore Cases are all linet with the best Silk-Velvet. Nos. 8051,8052 and 3053 , lined with Cotton-Velvet, will be $\$ 5$ less. 


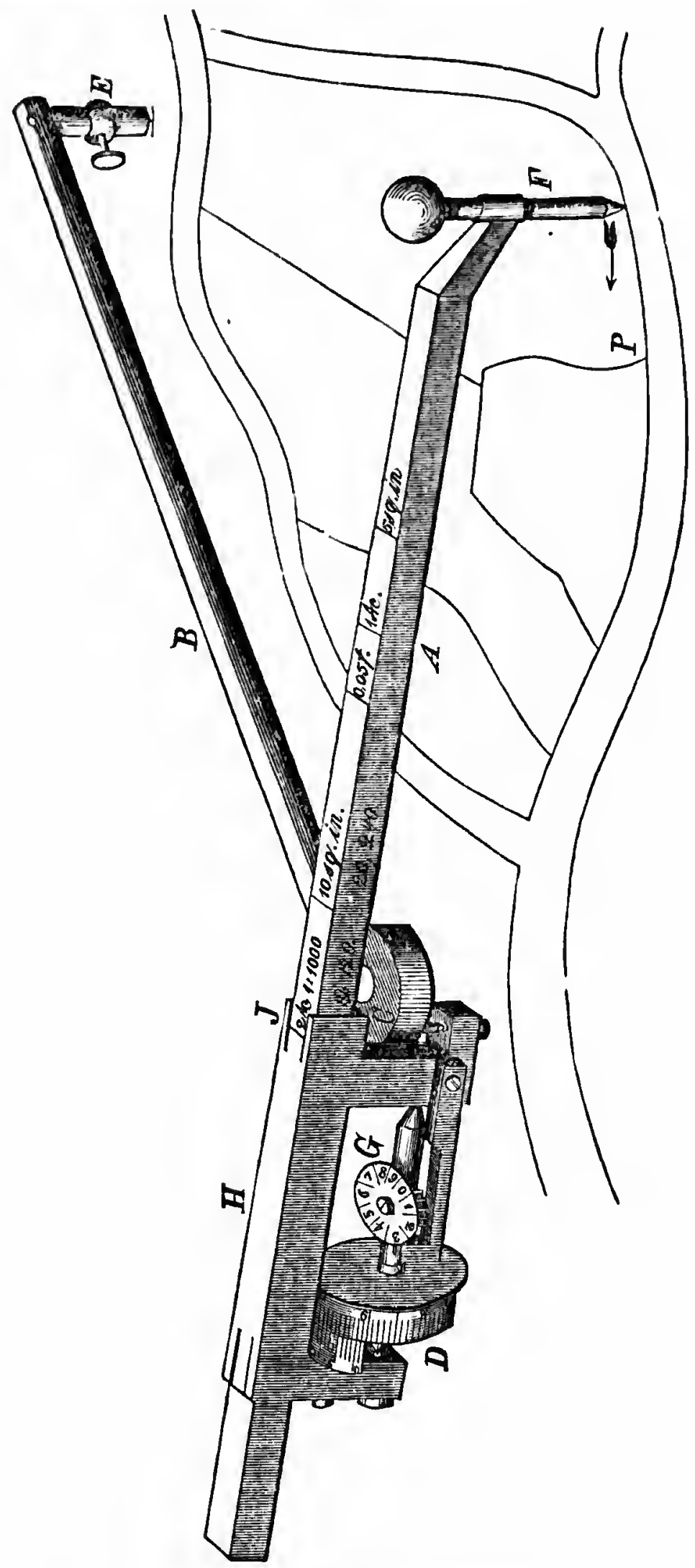

3059

AMSLER'S POLAR PLANIMETER. 


\section{Dirrtions for otsing Amsler's flolar gllaminctet.}

By means of Avsler's Patar Plasiareter, a person entirely ignurant of Gaometry, may aseertain the area of any planimotricol figure, bo matter how irregnlar its ontlines nity br, morecorrectly, amd in much shorter time, than the nost. experienced Iathematician could calculate it.

The inangement of the Instrument can be casily learned in half an hour, and in size it is no larger than a two-feet folding rule.

The 1'amineter indieates square feet, or square inches, and uores for surveying.

Dinzerioss. - Preparatory to the 480 of the Instrument, ascertain its state:The Index Roller D must play ensily, without ooming in eontact wilh the nonits, (or vernier.) The scrow centres, on wlich its axis revolves, must be ailjusteil so as to allow perfect freedom of rotalion; the same is to be observed fur the centre pin $\mathrm{C}$.

The needle point $F$ onght to project but very little from itg socket. Grent earo must be tuken not to bend any part of the instrument.

To ascortain the area of a figure in squaro inches, slide the squnre rot $\mathrm{A}$ into the tube II, so that the line marked $10 \mathrm{sq}$. in. (10 square inches,) stands fair with the bevelled part of the tate $J$. Then set the instrument on the paper, rotlint the index roller $D$, the tracing point $F$, and the needle point $E$, rest on the paper ; press the latter point a litile on the paper-not enough to pieree it tlirongl. 'This point is to remain stationary during the whole operation. Set the traeing point $E$ on any point $T^{P}$ of the outline, and mark that point, and real off the stute of the counting wheel $G$, and the index roller D. Suppose the counting wheel indieater 8 (as in out), the index roller 905 (90 degrees to be rend on the findex roller, und 5-10 on the nonius,) so that the $O$ of the nonius stands on $905-1000$ of the circumference of the index roller. Write down the number just rend off thus, 3,305 .

Now follow, with the tracing point $\mathrm{F}$, the outline of the figure, or part of the figure to be measured, with grent exactness, in the snme direction as the hands of a watch wonld move, until you arrive at the starting point.

Straight lines may be followed along a rule; then read off again the state of the indicators. Suppose you find now $5,768, z$, the counting whed indicating 5 , and the index roller and nonius 76 3-10 degrees. From these two readings, tho area found is to be obtained, and here two points are to be considered.

A. If the reedle point $\mathrm{E}$ is outside of the figure just traced round, the first number $(3,905)$ is to be deducted from the second number $(5,763)$.

\begin{tabular}{|c|c|}
\hline \multirow[b]{2}{*}{ ireo } & $\begin{array}{l}5,763 \\
8,905 \\
\end{array}$ \\
\hline & 1,858 \\
\hline
\end{tabular}

B. If the needle point $\mathbf{E}$ is inside of the outlines of the figure, ndd to the number last read off $(5,763)$ the number marked on the side of the square rod next to where $10 \mathrm{gq}$. in. is marked on the ppper side.

In this cose, it is 20,240 , the last number 5,763 read off

The number on side

20,240

$\begin{array}{lr}\frac{20,290}{26,008} & \text { Deduct from this } \\ \text { amount the number first read off, } & \frac{3,905}{22,098} \text { Multiply this remainder by }\end{array}$ ten, equal 220,98 , and this is the amount of square inolies, or area of the measured figure.

It is of no consequence whether the roller moves inside or outside of the outlines of tho figure, provided it moves on a smooth surface even with the figure.

To obtain the area in square feet, slide the square rod into the tibe up to the line marked 0,1 s\%. $\mathrm{ft}$. or $0,05 \mathrm{sq}$. ft. In this ease the differcnee between ilie tirst and second realings of the indicators is to be multiplied by 0,1 or 0,05 . If the 
lifferenes, for instnnee, is 4,653 , the rod being up to the line markel 0,1 eq. $f$.,

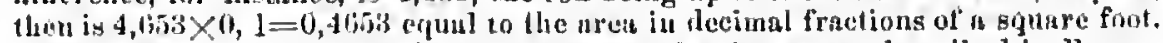

If the newlls: punt is within tho outlines of the tigures as described in $\mathbf{B}$, proceenl tho sinmo winy as at 13 , lint multiply by 0,1 or 0,05 .

If the figure to lug nensurerl is at a rulucel soale, the result lina to be multiplien

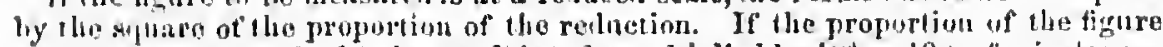
io tha full sige is as $1: 10$, the result is to le nulliplied by $10^{2}=10$ - for instance: the rosilt of tho first eximple is 1,858 , which, multiplied by $100,(1,858 \times 100)=$ Ikisk nit. incliey, would ho the amount of the areu.

If the numout of utres is to lie aseertained, the proportion of the reduetion being 1 : 1(100), slinle the silunre rod up to the liue marked 2 ac. $1: 10(0)$, or 1 ac.. uni opente ar indicald ahove; the result is to be multiplied by 1 or 2 , instead of' 111 or 5 . If the roul is set up to tho line marked 1 ac, no multiplication is nectesingy.

Slowil the plan of the piece of land be drawn on a smaller scale than 1-100i) fur cratuple. 1-ju(w)th-then muliply the result with the square of the proportion

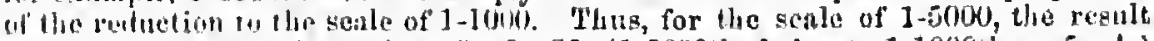
wonld linve to be inuliplied by $5 \times 5=25$, (1-50001/g being to 1-1000th as $6: 1$. It the scale is $1-5, j 0 t h$, multiply the result by $d^{2}=f$, that is to say, divide the result liy 4 .

kemark. - If, on realing off the horizontal or counting wheel, $G$, the indientor mints nets the middle line between two figures, say between 3 or 4 , then see how thi iulux toller stunds to the nonius. If the 0 on the nonius is on the lower side of the 0 of the ruller, therefore near 100, then read 3 ; but if the 0 on the nonius is on the uppur sile, therefore near 0 on the roller, then read 4 for unity.

If' the lubizontal wheel turns on its axis during the irneing operation, so that it goes beyond 0 , (in fact 10 ,) and even marks several revolutions, and then stops at nuy number-for instance, 7 -you rend 17 or 27 , \&e., adding as many times ten as the wheel has made full revolutions.

It is easy to notiee the number of revolutions. If the wheel $G$ marks 6 , and the rollur $\mathrm{D}$ is, for instance, on 0 degrees $7-10$ degrees, or on 4 degrees $7-10$ degrees, then the rending is of course 6,007 , or 6,017 . The number read off the uonius always taking the flird place after the units.

'The cut sliows the actual size of the Instrument.

Irice in Box 68300

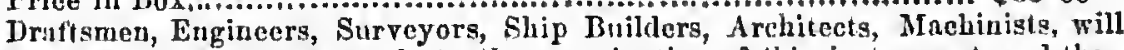
plense devote a few moments only to the examination of flis instrument, and they will at once bo convinced of its great importance and value. 


\section{äthtramatical 3ustruments.}

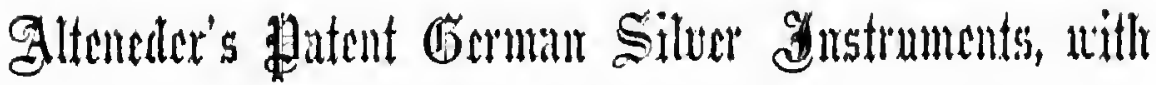 Gittuncter's totatent doint.}

No.

Price.

3060. Pair 6-inch needle-point Dividers, joint in eneh leg, with pen, pencil, and lengthening bar,..........................................

3061. Pair 3-inch ncedle-point Dividers, joint in eael leg, with pen and pencil points.

3062. Pair 3-inch necdle-point Dividers, with needle-point and pen,..... 3063.

3064. "6<smiles>[13CH3]</smiles>

"6 pencil,..

Pair 6-inch Dividers, with Irair Spring

"5-inch " " "

"3z-inch "

"6-ineh Plain Dividers

"5-inch

"3i-inch "

3068 .

8069.

3070.

3071.

2072 .

3073.

3074.

3075.

Bow Pen, German Silver, with needle-points.

$$
\text { \&s st and pencil leg,...... }
$$

Steel Stepping Dividere,

“ Bow P'en,

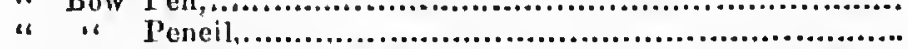

Proportional Dividers, 7 -inch, with Rack movement, aud all points movable, which enables the instrument to bo used a mucl greater length of time,

3076, Benm Compass, 24 -inch, in threo I3as, with pen, peneil, necdlepoint, and two straiglat points.

3077. Beam Compass, 36-incl, in 3 Bars, with pen, pencil, needle-point, and two straight points,

3078. Benm Compass, 48 -inch, in 3 I3ars, with pen, peneil, needle-point, and two straight points,........................................

3079, Furniture fur Bean Compass, with improved Micrometer aljustment, with pen, pencil, needle-point, nnd two straight points...

3080. Firniture fur 13eam Compass, same ns nbove, but graduatcd,......

3081. Jbuswood Besmy for the ubuve, 36 inches long,.........................

3082. Buxwool Beams, graduated to 10 th of an inch, 36 inches long... 
No.

Price.

3083. Protractor, German Silver, 6-inch, half circle, with Vernier, reading to 3 minutes, f degrees, with steel point dotter-a new and rery lesirable inst,rument,

8081. Protructor, Germnn Silver. 8-iuch, half circle, $f$ degrees, with Vornier, renling to minutes, and needle-point dotter,............ 308.i. Irotractor, German Silver, 8-inch, wholo circle, with Vernier, rending to miuutes. 1 degrees, with neelle-point dotter,.........

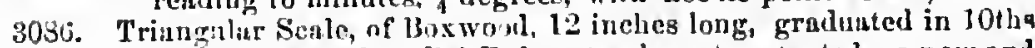
o1 1.ths, with limallel linler attachment, yntentel-a new and very complete instrument

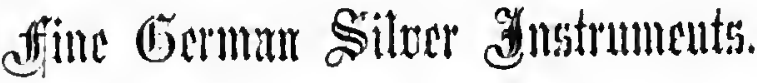

OF THE GEST GERMAN MAKE, BUT NOT EQUAL TO THE SWISS.
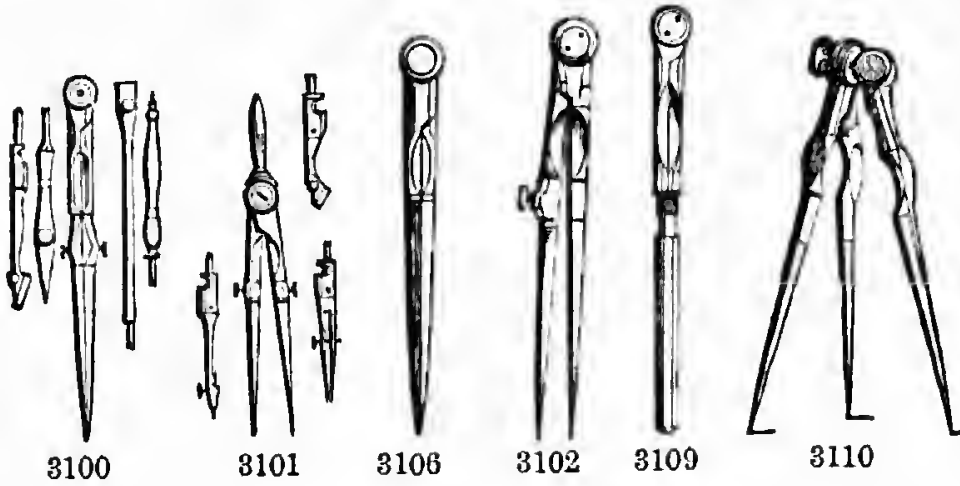

3100. Dividers, German Silver, stecl joints, 6 inches long, with pen, pencil necdle point, and lengthening bar.

3101. Divilers, German Silver, 3 inches long, with pen, pencil and

3102. Dividers, German Silver, steel joints, 7 in. long, with hair spring,

3103.

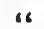

3104.

3106.

3107.

3108.

3102.

3110.

$\begin{array}{ll}6 & \prime \prime \\ 5 & 4 \\ 4 & \prime \prime \\ 6 & 4 \\ 5 & \text { “ }\end{array}$

16

$\because$

66

co

66

6 


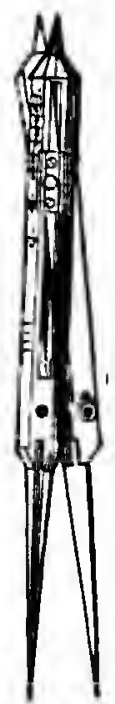

3111

3113

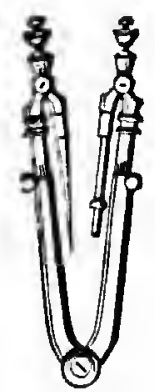

3114
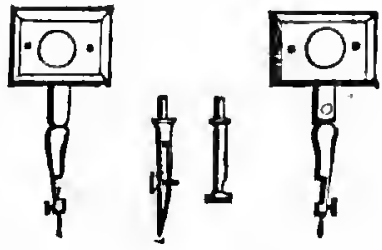

3115

No.

Prico.

$\$ 900$

1100

350

850

700

200

300

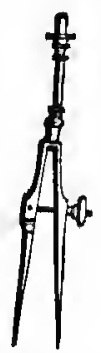

3118

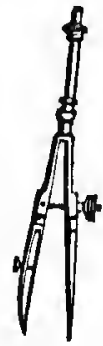

3119
‘) "

"r graduated to 10 ths,

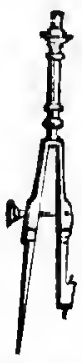

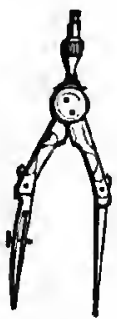

3123

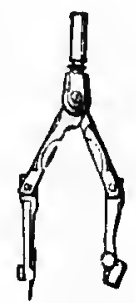

3124

3118. Steel Spacing Dividers, all Steel, with Metal Handle,................

3119. "Bow Pen, " "

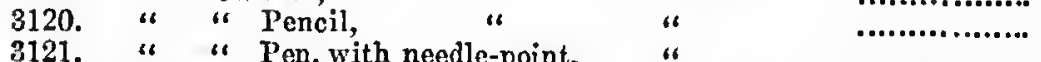

3122. " " Pen, with needle-point, "

3123. Dividers, German Silver, steel joints, with pen, joints in each leg,

3124. Dividers, German Silver, steel joints, with pencil, joints in each leg, and needle-point, 


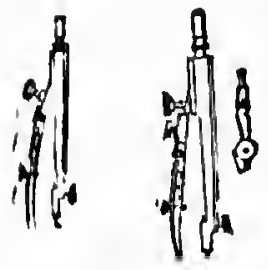

3125
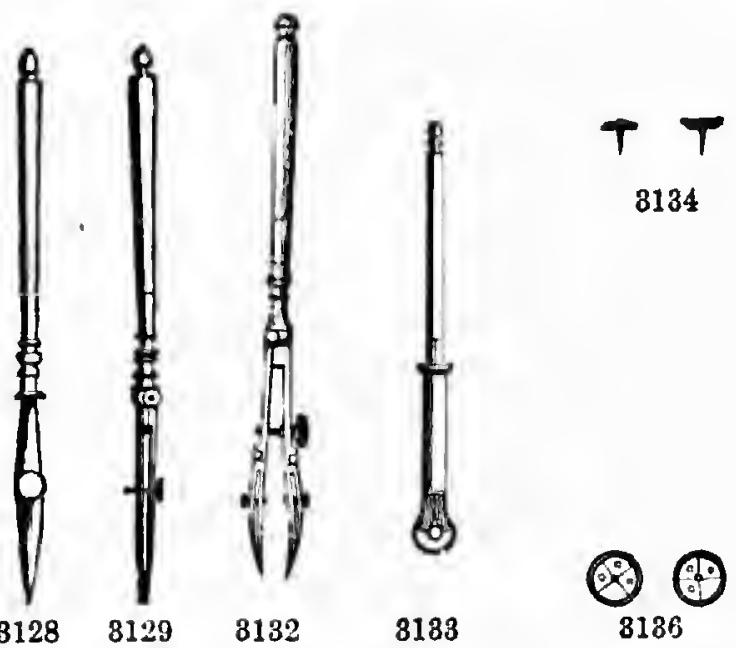

8186

Price.

3125. Bow Pen, German Silver, with adjusting spring and needle-point,

3126. Bow Pen, " " "f "finish,...

\$127. " German Silver, with adjusting spring, needle-point, and

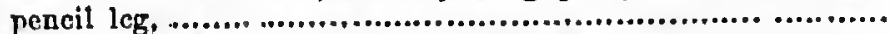

3128. Drawing Pen, German Silver, hinge to pen, ........................

3129. " " "

3130. Drawing Pen, German Silver, hinge to pen, and Protracting Pin, cxtra fine finish,.................................................

3131. Drawing Pen, all German Silrer, for Red Ink,.....................

3132. Rnilroad, or Double Drawing Pen, German Silver, tine finish,......

3133. Roulette, German Silver, for dotting lines,.............................

3134. German Silver Paper Tacks, flat heads,-per doz....................

3135. " " round " 4 ..................

3136. Horn Centres, German Silver rim, ench,..............................

3137. Map Perambulator, for measuring distances on Maps,...............

S. 00

260

325

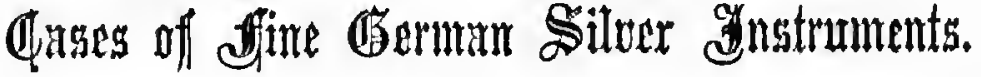

\section{FOR ENGINEERS, ARCHITECTS, AND MACHINISTS,}

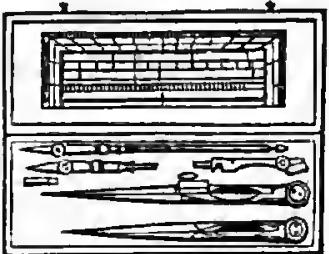

3203

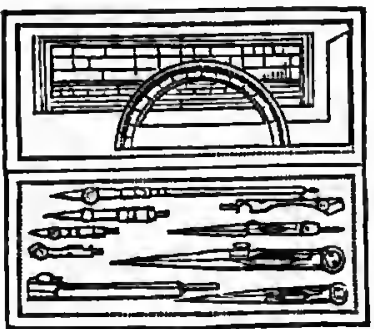

3206

3200. Morocco Box, containing pair 3-inch Dividers, with pen, pencil, and needle-point, 
No.

Prico.

3201. Morocco Box, oontnining

Pair 3-inch Dividers, with pen, pencil, and needle-point;

One Drawing Pen.

3202. Morocco Box, containing

Pair 54 -inch Divilers, with pen and pencil;

Pnir ס-inch Plain Dividers;

Drawing Pen,

3203. Same ns No. 3202 , with aldition of Ivory Protractor Scale, inches long.

3204. Morocco Box, containing

Pair 5 -inch Dividers, with pen and pencil;

Pair 5-incl Lividers:

Prair Stecl Spacing Dividers;

Drawing Pen

3205. Same ns No. $320 \%$, with addition of lrory Protractor Scale,..........

3206. Morocco Box, containing

Pair 5.-inch Dividers, with pen, pencil, and lengthening bar;

J'air 5-inch Plain Dividers;

I'air 3-inch Dividers, with pen and penoil;

Drawing Pen;

German Silver Protractor;

$$
\text { “" Triangle, }
$$

3207. Same as No. 3206 , with tho addition of Ivory 6 -inch Scalc,........

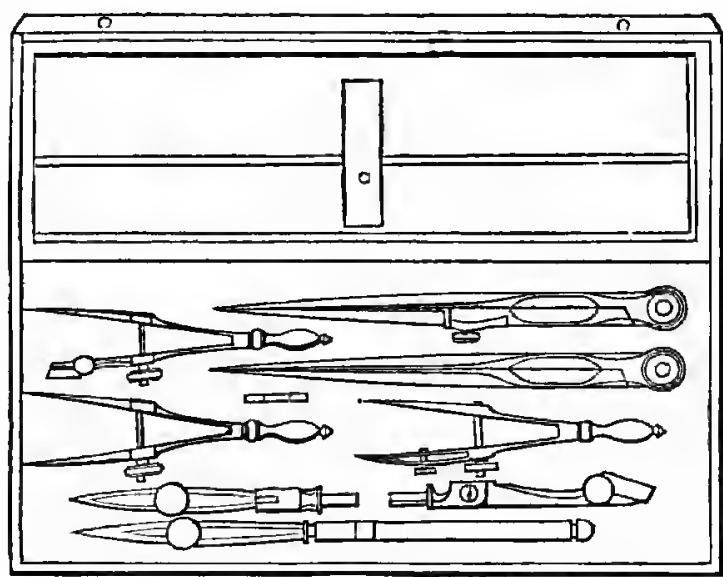

3208

3208. Morocco Box, containing

Pair 51-inch Dividers, with pen and pencil;

Pair 5-inch Plain Dividers ;

Pnir Steel Spacing Dividers;

$$
\text { “ Bow Pen; }
$$

Drawing Pen;

German Silver Protractor;

Irory 6-inch Scale, 


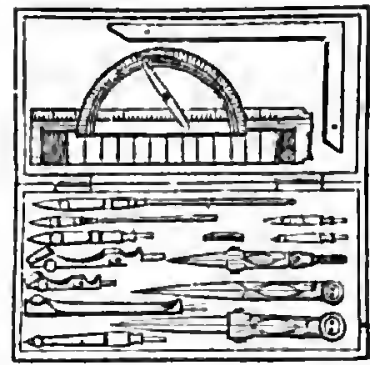

3208

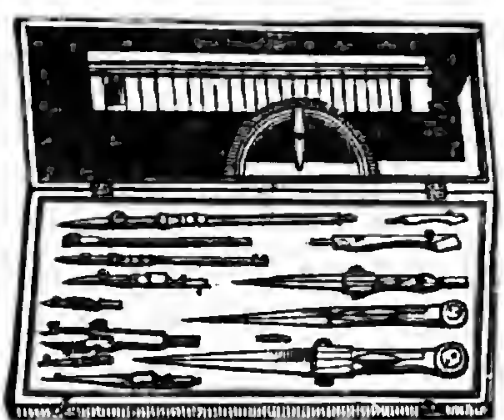

$3: 1$

No.

Price.

3209. Moroceo Box, contrining

Pair 5/-inch Dividers, with pen, pencil, needle-points, and lengthening bar;

Pair 5-inch Plain Dividers;

Pnir 3-inch Dividers, with pen, pencil, and needle-point;

Two Drawing Pens;

German Silver Protractor:

Gcrman Silver Square;

Ivory 6-incli Scalo,

3210 Samo as No. 3:09, in a polished Wulnut Box.........................

3211. Polished Walnut Box, containing

Pair 5t-inch lividers, with pen, pencil, needle-point, and lengthening bar;

Pair 5-inch Plain Dividers;

Puir 8-inch Dividers, with pen, pencil and needle-point;

Bow Pen, German Silver, with adjusting spring and needlepoint;

Two Drawing Pens;

German Silver Protractor, divided to 1 degrees;

German Silver Square;

Ivory 6-inch Scale..

8212. Morocco Box, eontaining

Pair 5t-inch Dividers, with pen, pencil, needle-point, and lengthening bar;

Pair 5-inch llair Spring Dividers;

Pair 5-inch Plain Dividers;

Pair 3-inch Dividers, with pen, pencil, and needle-point ;

Two Drawing Pens;

German Silver Protractor, divided to 1 degrees;

German Silver Square;

Ivory 6-inch Scalc.

3213. Polished Walnut Box, containing

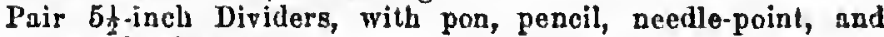
lengthening bar:

Pair 3h-inch Dividers, with pen, poncil, and needle-point;

Pair 5-inch Iair Spring Dividers;

Pair 5-inch Plain Dividers;

Spring Bow Pen, with needle-point and sdjusting spring;

Two Drawing Pens;

German Silver Protractor;

German Silver Square;

Boxwood Triangular Soale, 12 inches long, 
No.

Price.

3214. Folished Rosewood Box, with Tray, Lock and Key, giving space below for Colors, India Ink, und containing

Pair 61-inoh Vividers, with rounded points, pen, peneil, needlopoint, and lengtlening bir;

Pair 6-inch Hair Spring Dividers;

Pais 6 -inch Plain Dividers:

Pair 3-inch Dividers, with pen, pencil, and noedle-point;

Steel Spacing Dividers;

Bteel Bow Pen;

Steel Bow Pencil;

Pair l'roportional Dividers, 9 inches long, with Rack;

Railrond Drawing Pen;

Three Urawing lens;

Furniture for ifood Benm Compasses;

Germun Silver Protractor;

Horn Protractor;

One Wood Curre;

One Wood Triangle;

Box Triangular Seale, 12 inches long;

Ehony Parallel Rule, 12 inches long;

12 Paints, India Ink, Slabs, \&e., \&e.,

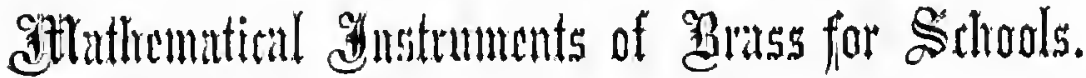

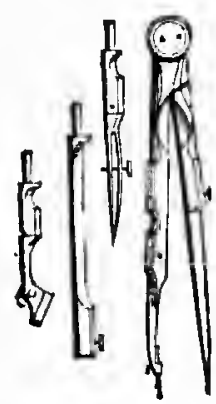

3224

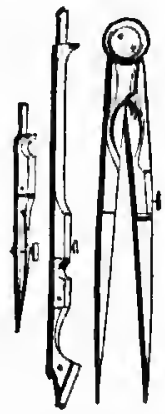

3225

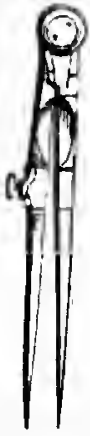

3228

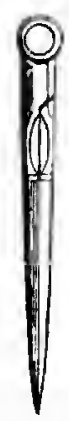

3232

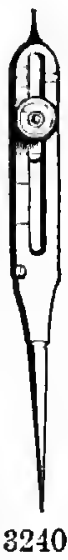

No.

3204. Dividers, Rrass, steel joints, 6 inehes long, with pen, pencil, needle point, and lengthening bar,...

, 3225. Dividers, Brass, steel joints, 6 inches long, with pen, pencil, and lengtheniug bar,

3226. Dividers, Brass, steel joinis, 5 inches long, with pen, pencil, and lengthening bar,

3227. Dividers, Brass, steel joints, $4 \frac{1}{2}$ inches long, with pen, penoil, and

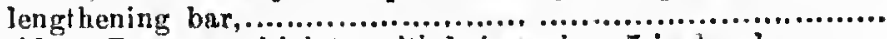

3228. Dividers, Brass, steel joints, with hair spring, 7 inches long,......

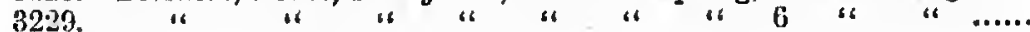
3230 .

"

Pripe. 
No.

$3: 31$ 2032. $3: 33$. $3: 34$. 320.5. 3236. 3287. 3238. 3239. 3240.
Divilers, Brass, steel joints, plain, fine finish, 7 inches long, $\cdots . .$.

a
a6
6
6
6
66

$$
\text { plai }
$$

"lain, fire finish, "6

" medlum "

a)

"

"6

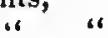

Price.

$\$ 1$ on

100

85

c,0

60

60
25

25

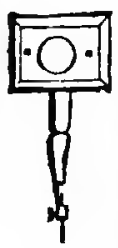

3243
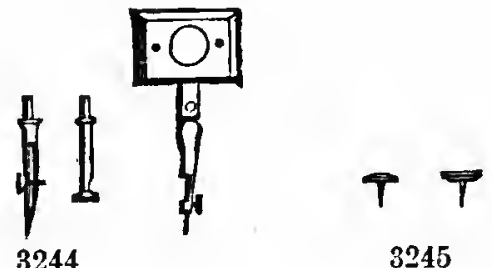

3245

3241. Bow Pens, Brass, with adjusting spring,....

$\$ 100$

100

3242. Bow Pencils, Brass, with adjusting spring, .........................

3243. Drawing Pens, Brass, Black Handlc,................................

3244. Furniture for Bcam Compass, with Micrometer adjustment, pen, pencil, and necdle points,

3245. Brass, Paper, Tacks, per doz........................................ 


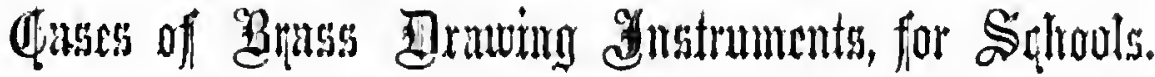

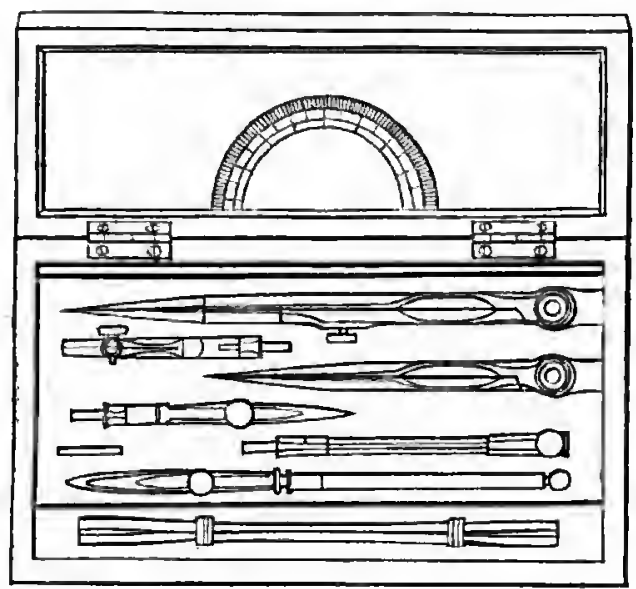

3250.

No.

3250. Polished Mahogany Box, containing

Price.

Pair 6-inch Dividers, with pen, pencil, and lengthening bar;

Pair 6-inch Plain Dividers;

Drawing Pen;

Horn protractor,

32.51. Same as No. 3250, with addition of 6-inch Boxwood Plotting

Scale,......

3252. Same as No. 3251, with the addition of Ebony 6 -inch Parallel Rule,

3253. Polished Mahogany Box, containing

Pair 4t-inch Dividers, with pen, pencil, and lengthening bar;

Pair 4-inch Plain Dividers;

Drawing Pen ;

Brass Protractor;

Wood Rule;

2 Wood Triangles;

4 Colors, 2 Color Cups;

India Ink, Brushes, and Crayon Holder.

3254. Same as No. 3253, with the addition of 6 -inch Boxwood Scale,....

3255. Same as No. 3254, with the addition of Ebony Parallel Rule, 6 inches long.

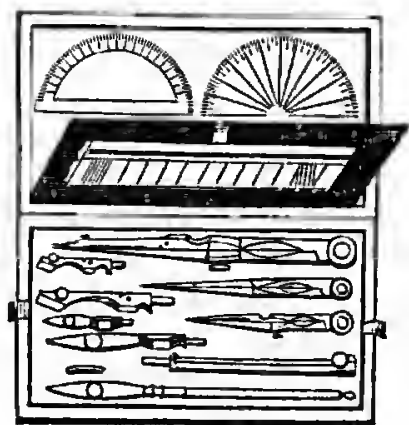

3256. 
No.

Prioe.

3256. Polished Rosewood Box, with Tray, and Lock and Key, containing

Pair th-inch Dividers, with pen, poucil, and lengthening bar;

Juir 5-incl plain dividerg;

Pair 32 -inch Dividers, with pen and pencil;

Drawing Pen ;

Brass Protractor;

Jorn l'rotractor;

Boxwood Scale, 6 inches long,....................................

3257. Same as No. 3256; but has Ivory Plotting Scale, 6 inclies long, in place of the Boxwood, ............................................

8258. Same ag No. 8257 with the addition of Ebony larallel Rulc.......

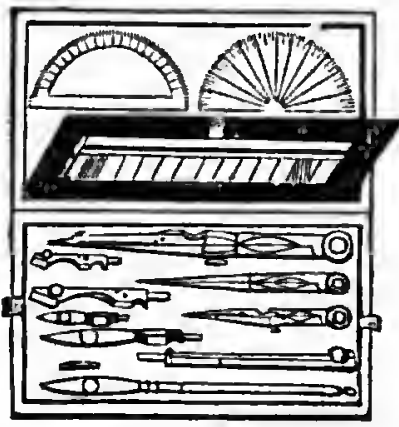

No. 3259

3259. Polished Rosewood Box, with Tray and Lock and Key, containing:-

Pair of 6-inch Needle Point Dividers, with Pen, Pencil and lengthening bar;

Pair 5-inch Plnin Dividers;

Pair 8 -inch Dividers, with needle point, pen and pencil ;

Drawirg Pen;

13rass Protractor;

IIorn Protraetor;

Ivory Sealc 6 inches long,

3260. Same as No. 3259, with the addition of Ebony Parallcl Rule

(i) inches long....

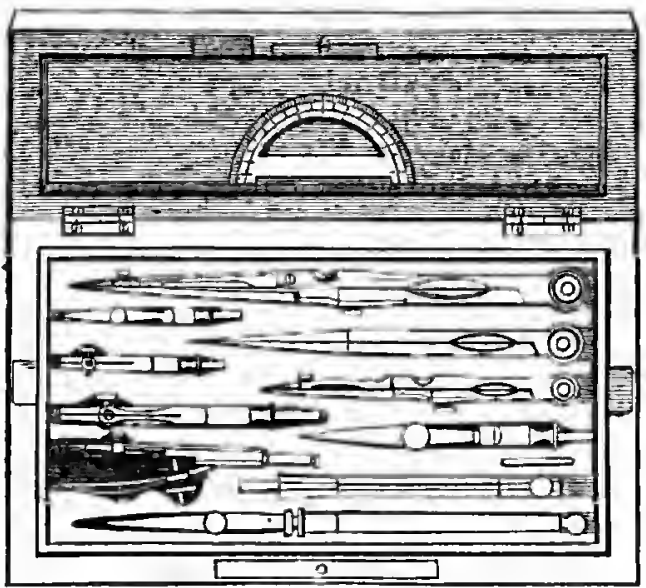

No. 3261 . 
No.

2961. Polished Rosewood Iox, will Trny, nnd Lock nnd Key, oontaining :

Pair 6-iuch Needlo Point Dividers, with pen, pencil aud lengthening bar:

Pair 5-indh Plain Dividers:

Puir 3]-inch Necule loint Dividers, with pen nnd pencil ;

Spring Bow Pen, with adjusting screw und noodle point;

Drawing Pen :

Irass Protractor;

Horn Protractor:

Irory Plotting Sealo, 6-inches long ...................................

3262. Same as No, 3261, with the addition of Ebony Parallel Rule.......

3263. Same as No. 3261, with the nddition of a pair of Proportional

Dividers ...............................................................

3264. Samo ns No. 3261 , but the instruments aro of tho very best quality, nnd all the dividers have rounded points..............................

3265. Samo as No. 3:64, with addition of Parallel Rule, and a pair of

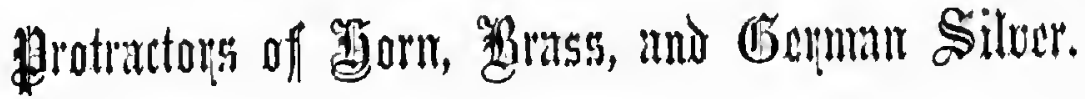

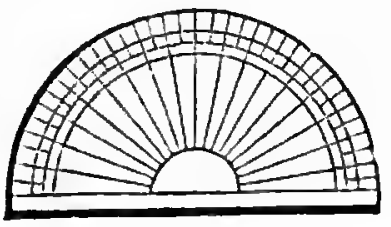

3270 .

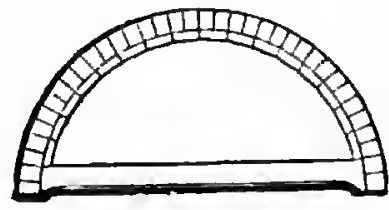

3275.

3270. Horn Protractor, 4-inch Diameter, $\frac{1}{3}$ Circle

3271.

3272.

3273.

3274.

3275.

3276.

3277.

3278.

3279.

3280 .

3281.

$\begin{array}{cccc}\text { " } & \text { " } & 5 & 6 \\ \text { "6 } & 6 & 7 & \text { " } \\ \text { Brass } & \text { " } & 8 & 14 \\ \text { "6 } & 4 & 4\end{array}$

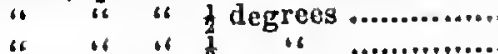
a) 66
16 a
"6
" 16 " "

"insido Centre \& Circle...............

German Silver Protractor, 4 inches diameter,

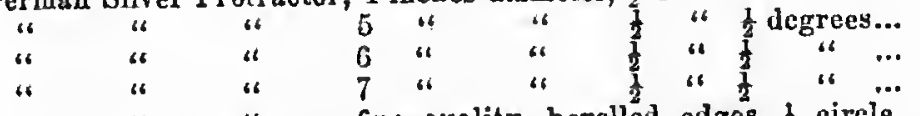

" " " fine quality, berelled edges, $\frac{1}{2}$ circle,

7) degree, 4 inches diameter

3282.

3283.

3284.

3285 .

3286.

3287.

8288.

3289.

G. S. Protractor, 5 inches diameter, $\frac{1}{2}$ circle, $\frac{1}{3}$ degrees, fincst quality

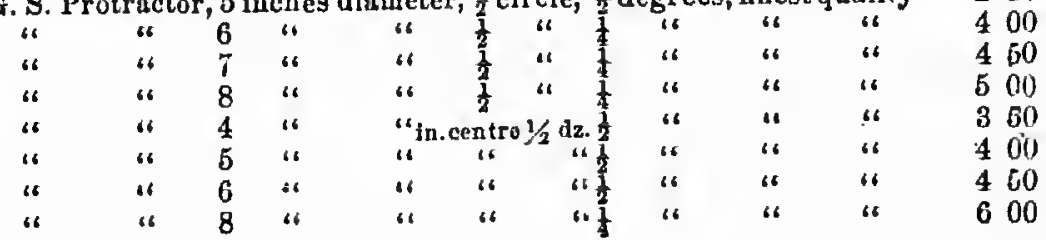

$\$ 025$

050

075

100

125

025

050

075

125

150

325

175

250

400

460

500

60

00

600 


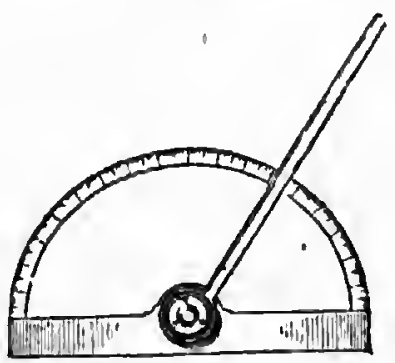

3290.

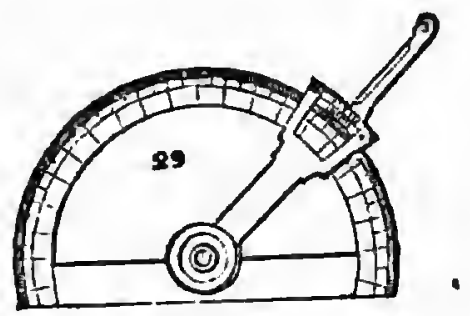

3293.

No.

8290. Germnn Silver Protractor, with Morn centre and morcable Arm,

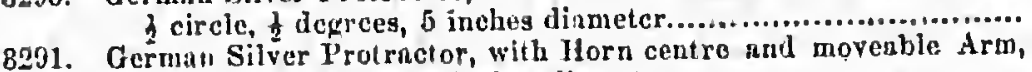

Price. 1 circle, $\frac{1}{2}$ degrees, 6 inches diameter...............................

5292. Germinn Silver I'rotractor, with IIorn centre and moveabie Arm, $\frac{1}{2}$ circle, 1 degrece, 8 jnches diameter.................................

3293. Gornan Silver Protractor, with Horn centro and moveable Arm, and Vernier, $\frac{1}{2}$ circle, $\frac{1}{2}$ decrees, 5 inches dismeter................

3294. German Silver Hrotractor, with Horn centre and moveable Arm, and Vernier, reading to tbrce minules, t circle, t degres, 6 inches dinmeter. ......................................................

3295. German 8ilver Hrotractor, with Horn centre and movenble $\Lambda \mathbf{r m}$, and Vernier, reading to minutes, 1 circle, 1 degrees, 8 inches

3296. German Silver Protractor, whole circle, 5 inohes diameter,

3297. German Silver Prolractor, whole circle, 6 inches diameter, $\frac{1}{2}$ degrees...........................................................

3298. German Silver Protractor, wholo circlo, 8 inches diameter, $\$$ degrecs............................................................

3299. German Silver Protrictor, wholo circle, with Horn centre and moverble $\Lambda$ rm, 5 inclscs diameter, $\frac{1}{2}$ degrees......................

3300. German Silper Protrictor, whole circle, with Horn centro and moverble Arm. 6 inolies diancter, $\frac{1}{2}$ degrees........................

3301. German Silver Protrictor, wholo cirele, with Horn centro and movenblo $\mathrm{Arm}, 8$ inches diameter, 1 degrees........................

3302. German Silver Protructor, whole circle, with Arm and Veruier, Ilorn centre, 5 inches diameter, 1 degrees ..........................

3303. German Silver Protructor, whole circle, with Horn oentre, moveable Arm and Vernier, reading to three minutes, 6 inches diameter.

3304. German Silver Protractor, whole circle, with Horn centre, moveable Arm, and Vernier, reading to ninutes, 8 inches diameter

3305. German Silver Protractor, $\frac{1}{2}$ circle, with IIorn centre, moveablo Arm and Vernior, with needlo point dotter, reading to three minutes, 6 inches diameter, a new and rery desirable instrument.

5760

800

1000

900

1150

1600

$\$ 750$

900

1200

960

1175

1500

1200

1450

1625

1600

2200

8306. German Silver Protractor, $\frac{1}{2}$ circle, with Horn centre and Vernier,
with noedle point dotter, reads to minutes, 8 inches dinmeter... 


\section{Siviss flotrattors of OHormam Silunt.}

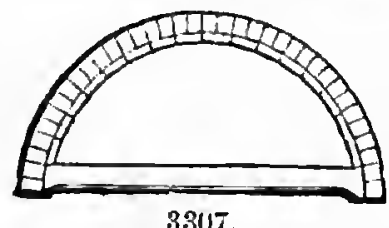

No.

3307.

3308.

3309.

8310.

8311 .

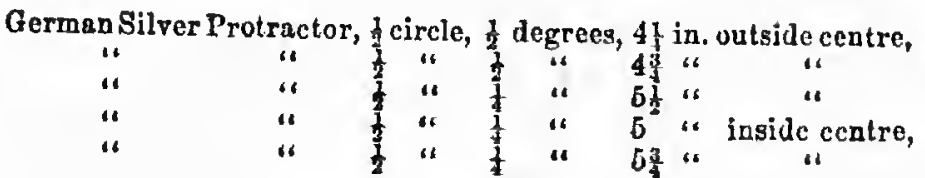

\section{3erud protrators.}

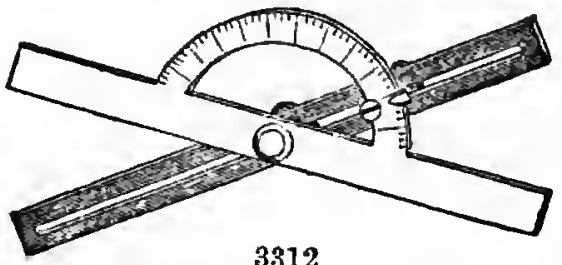

3312
Price,

$\$ 180$

250

400

275

450

8312. Bevel Protractor, all steel, with Arm 6 inches long, divided to degrees for machinists.

3313. Bevel Protractor, all steel, with Arm 10 inches long, divided to degrees, for machinists.

3314. German Silver Protractor, G-inch diametcr, 1 degrees, with Composition Blade 40 inches long.

2000

3316. Paper Protractors, 2 circle, 4 to 12 inches diameter..................25 to ,40

3816, " $"$ whole circle, 4 to 12 " " ...................25 to.40

\section{durory glyotractors.}

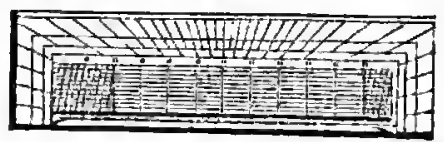

3320 .

3320. Irory Protractor, 6 inches long, 13 inches wide, whole degrees, with 6 scales of cqual parts, 4 scales of feet and inches, 2 scalcs

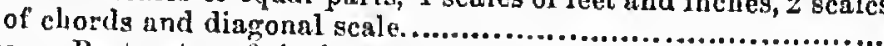

3321. Ivory Protractor, 6 inches long, $1 \frac{3}{4}$ inches, wide, $\frac{1}{2}$ degree, 8 suales of equal parts, 10 scales of fect and inches, 2 scales of chords, dingonal scale and line of 40 on lower cdge.............

3322. Ivory Protrnctor, 8 inches long, 2 inches wide, 1 degree, 8 ecnles of cqual parts, 10 scales of feet and inches, 2 scalcs of chords, 
No.

dingonal scale, and line of 40 on lower edge.

$\$ 575$

33.33. Irory l'rotrnutor, 12 inches long, 2 inches widẹ, $\frac{1}{2}$ degree, with 1) smilus of equal parts, 12 scales of feet and inches, 2 scales of chords, diagonal seale, and line of 40 on lower edgc...........

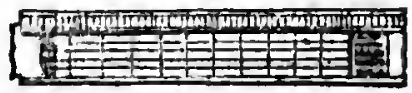

3828.

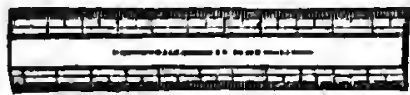

3329 .

8328. Ivory Plotting Scale, 6 inches long, same as in school cases of inIrory Chain Scrie, 12 in. long, graduated on two edges 10 and 20 ,

3329. Irory Chain Scrle, 12 in. long, graduated on two edges 10 and 20 ,

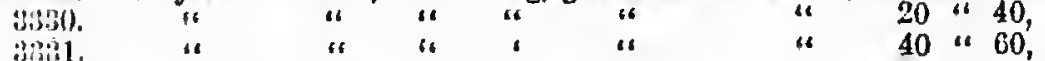
imi32. 2.833. 4004040 "

$\$ 080$

375

375

875

375

375

\section{Boxtoond Sitales.}

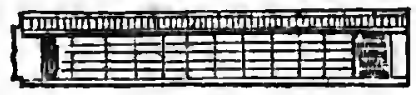

3340 .

3340. Boxwood Scales, 6 inches long, same as in School Cases of Instruments.

3341. Boxwood Scalcs, 12 inclies long, graduated to eighths of an inch, for Schools of Design......................................................

3342. Boxwood Gunter Scales.

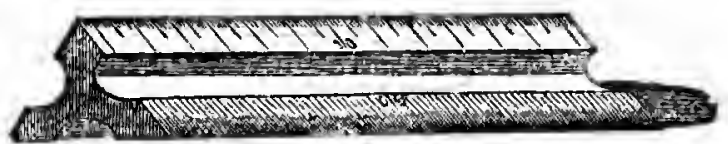

3315

3345. Triangular Scale of Boxwood, 24 inches long, fur Engineers, graduated to $10,20,30,40,5 \mathrm{n}$, and 60 to the inch...............

3316. Triangular Scale of Boxwood, 12 inches long.......................

3347.

3348 ,

3349. Triangular Scale of Boswood, 24 inches long, for Architects,

gradunted to $\frac{3}{3}, \frac{3}{1} \frac{3}{6}, \frac{1}{8}, \frac{1}{4}, \frac{3}{8}, \frac{1}{2}, \frac{3}{4}, 1,1 \frac{1}{2}, 3$ inches, and $16 t h s$

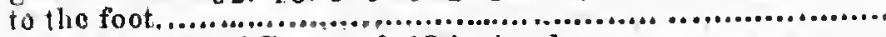

83.50 .

Triangtilar Seale of Boxwood, 12 inches long .........................

3351 .

8352.

3353.

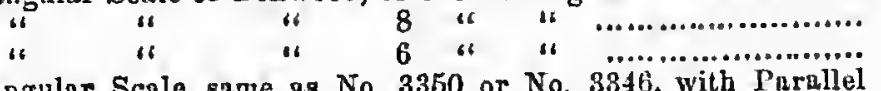

Triangular Scale, same as No. 3350 or No. 3346 , with Parallel Kule Attachment.

\section{plaper Sertes.}

3355. Paper Scalcs, nineteen inches long, 19 inches wile, for Architects and Engineers, in sets of six. 
No.

Series A contains 6 Scales, one each, divided to $\frac{1}{2} \frac{1}{2}, 1,1 \frac{1}{4}$, and 3 inclies to the foot-per set.

Series 13 contains 6 Scales, ono each, divided to $\frac{3}{3}, \frac{1}{8}, i^{3}$, in $^{3}$

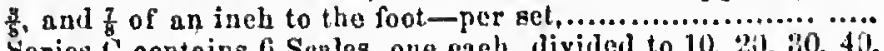
Series $\mathrm{C}$ contains 6 Scnles, one eaeh, divided to $10,21,30,40$, 60 nnd tio parts to the inch-per set,

Separate Seales of any of the above, ench.

The advantages of these Seales are-they expand and eontract nearly the same as drawing paper, do not soil the work, and distanees can be set off from them without tho use of diriders.

\section{Stent cillets.}

\section{UNITED STATES STANDARD}

3356. Steel Rule, 24 inches long, divided to 8 ths, 10ths, 12ths, 14ths, 16ths, 20ths, 21ths, 28ths, 32ds, 48ths, 60ths, 64ths, and 100 ths of an inch.

3357.

Steel Rule, 12 inehes long,.............................................

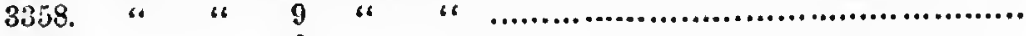

3359.

3360 .

3361 .

3362 .

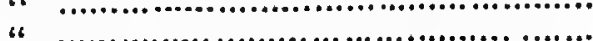

646

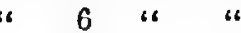

s6 640 is 4

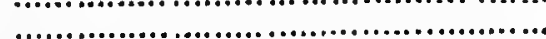

" a 3

as

Steel Shrink Rule, 241 inehes long, divided to 1 and $32 d s$,

for Moulders and Niehinists......................................

3363. Steel Strink Rule, $24 \frac{1}{4}$ inches long, graduated as above, and one sido graduated to inches............................................

3364. Boxwood Shrink Rule, 21t inches long, graduated like No. 3362.

150

100

\section{Sted Squares, for citluctrinists.}

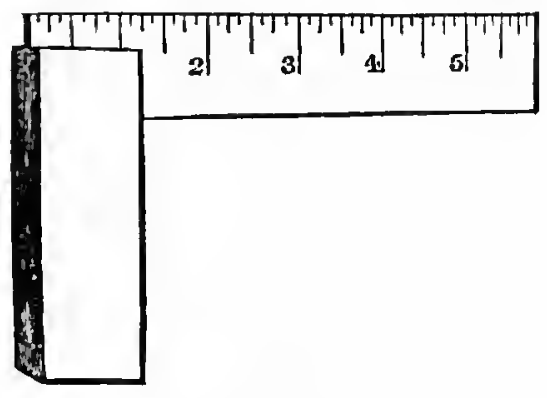

3367.

3.365. Steel Square, Blade 12 inehes long, divided to $32 \mathrm{ds}$,

" "

",

"4

$\begin{array}{ll}9 & \text { " } \\ 6 & \text { " } \\ 4 & \text { " } \\ 3 & \end{array}$

"

".

66

..................

...................

3369 . 


\section{Gamcs' datent olniversal Siquare.}

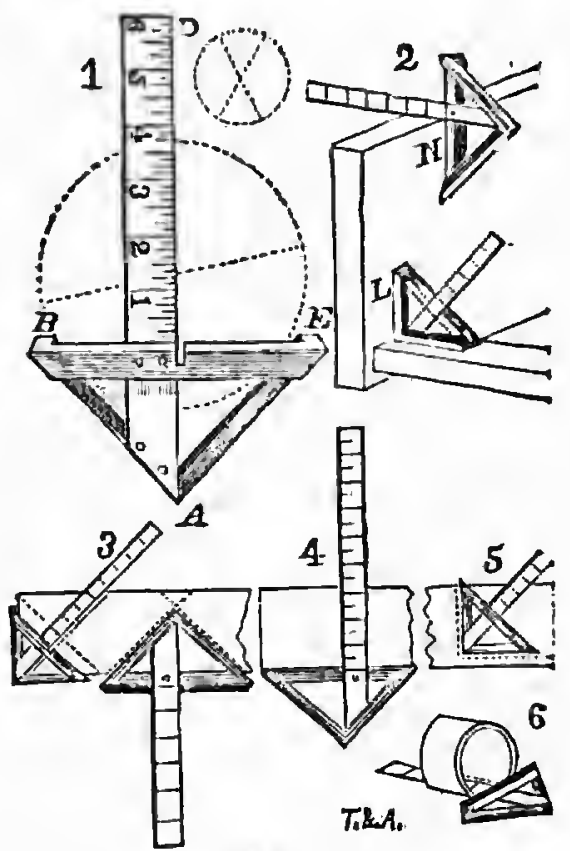

3370.

This Square combines, in the most convenient form, five different instruments: viz. The Try-Square, the Mitre, the T-Square, the Granuated Rele, and (what is entirely new) the Centri-Squane, for finding the centre of a circle.

Fig. 1 explains its applieation as a CentuE-Squark, Put the instrument over the circle, as the end of a bult or shnft, with the arms, B A, E A, resting againgt the circumference, in which position, one edge of the rule, $A D$, will cross the centre. Mark a straight line in this position; apply the instrument again to another part of the circumference, and mark nnother line crossing the first. Tho point where the two lines cross each other will be the centro of the circle. The whole is the work of a moment. Fig. 2 explains the application of the instrument as a Carpenter's Try-Square, $x$, and an OUTsips-Squale, $x$ - Fig. 3 as a MitreFig. 4 as a T-Squarb and a Graduaten Rute-Figs. 5 and 6 as an OUtaidz-Squate for drawing, and a T-SQUARE for machinists.

The tongue, n A, (Fig. I.) being fastenel, as it is, into tho triangular frame B A E, cannot be moved or knocked from its place-in this respect, constituting a great improvement over the Carpenters' Try-Square, T-Square and Mitre, in common use. The instruments are made of the best material, neatly finished, and perfectly true.

"Is a CENTRE-SQUARE alone, it is invaluable to every mechanic. * * * In short, it combines, in a most convenient form, so many useful instruments, no mechanic's list of tools on well be complete without a Universal Square." Sc. Ancr., Sept. 22, 1865.

No.

3370

3371.

3372 .

3373.
Ames Patent Uni

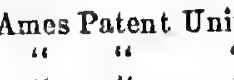

it 1

14 a

af
as

Price.

$\$ 500$

450

400

350 


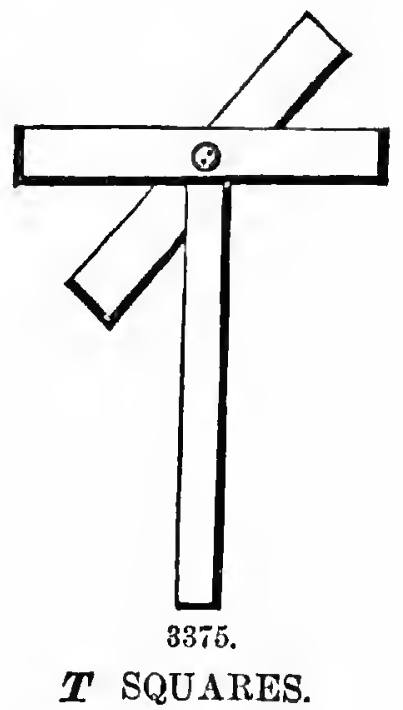

No.

3375. T Square, Fixed Head Blade, 18 inches long each.

3376.

3377.

3378.

3379 .

3380 .

3381.

3382.

3383 .

3384.

3385 .

T Square, Swivel Head Blade, made of three kinds of wood, $\ddot{24}$ inches long each.

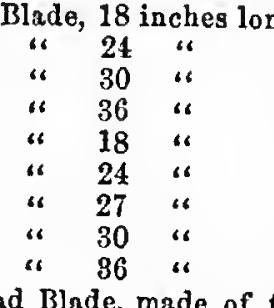

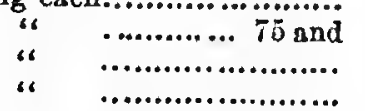

\begin{tabular}{|c|c|c|}
\hline & "6 & "6 \\
\hline " & "6 & "6 \\
\hline "6 & "1 & " \\
\hline "6 & Swivel & "1 \\
\hline 66 & a & " \\
\hline 4 & .66 & 66 \\
\hline 66 & 16 & “ \\
\hline & (6) & \& \\
\hline
\end{tabular}

Price.

$\$ 075$

125

090

100

150

175

200

200

250

200

3386. T Square, Swivel Head Blade, made of three kinds of wood, 36 inches long ench.

3387. T Square, Swivel Head Blade, with brass 8388 .

8389 .

Swivel Head Blade, with brass edges, 30 in. long each.
"" "6 " 36 " " 36 " takes off, and blade can be used as a rule. Blade, 30 inches long................

3390. T Square Head, takes off, and blade can be used as a rule. Blade, 36 inches long.

\section{Stad Strainlit Gednes.}

3391.

3392 .

3393.

3394.
Steel Straight Edges, 72 inches long

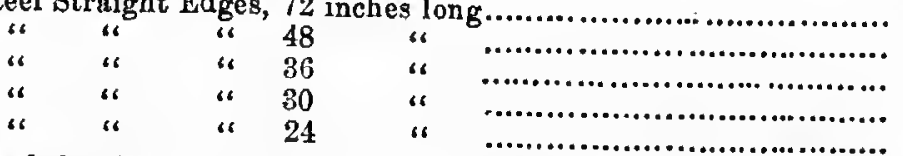

Steel Straight Edges, and Steel Blades for T Squares, made to order, of any length.
$\$ 1500$ 


\section{Triangles, Squturss and Cuuroes.}

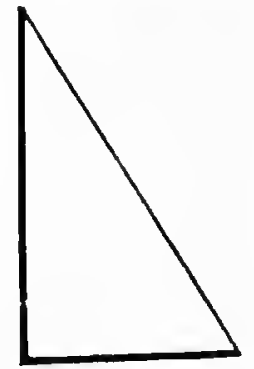

8395.

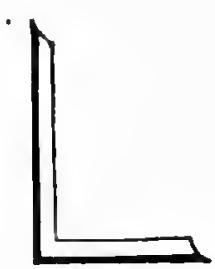

3407 .

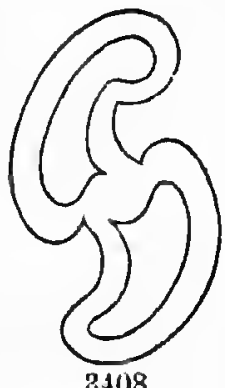

2408.

No.

3395. Whiterrood Triangles, 30, 60 and 90 degrees, perpendieular, 5 to 9 inches long.....................................................

8336. Whitervool Triangles, 30,60 and 90 degrees perpendicular, 9 to 12 inches long.

Price.

3397. Whitewood Triangles, 45,40 and 90 degrees............................... 90 very well-made perpendicular, 9 inehes long...................

3399. Triungle, framed of three kinds of wood, open eentre, 45,45 and 90 perpendieular, 6 inehes long ...................................

3400. Triungle, India Rubber, perpendicular, 6 inebes long, 30, 60 and 90 degrees, and 45,45 and 90 degrees.

3401. Tringle, India Rubber, open eentre, perpendieular, 7 to 10 inehes long, 30,60 and 90 degrees.......................................

3402. Triuncle, India Rubber, open eentre, perpendieular, 6 to 8 inches long, 45,45 and 90 degrees...............................

8103. German Silver Triangle, 30, 60 and 90 degrees perpendieular, 6 to 7 inehes long..

3404. German Silver Triungle, 30,60 and 90 degrees perpendienlar, 8 to 10 jnehes long...................................................

3405. German Silver Triangle, 45, 45 and 90 degrees perpendieular, 4 to 5 inehes long........................................................

3406. German Silver Trinngle, 45, 45 and 90 degrees, perpendieular, 6 to $T$ inclies long.

Nos, 3403 to 3106 are made with Trory buttons inserted in the German Silver, to prevent the trinngle from soiling the paper; the larger sizes have handles.

3407. Germnn Silver Squares, perpendieular, 6 inehes long................

3108. Whitewood Irregular Curves, various patterns................. each

3i09. IIorn "6 "

3410. Drawing Bonrd, half size, 15 by 21 inehes............................ 3411.

100

100

100

125

125

250

400

225

400

110

$0 \quad 25$

100

200

800 


\section{flarallel actutes.}

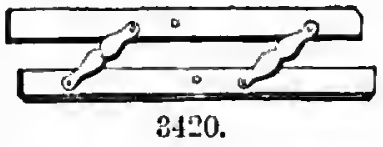

No.

3420. Parnllel Rules, Ebony, brass mounted, 6 inches lon

Price.

3121

$3+22$.

3.423.

3424.

$34 \div 5$.

$8+26$.

3427.

$3+28$.

3420 .

8430.

3431.

a"

"6
"4
"6
4
"6
"6
" Ebon

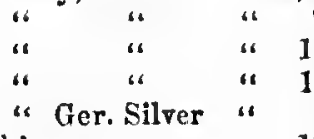

all brass,

is

if

on Rollers,

"s

"1

9
12
15
6
12
5
8
0
12
15

is

is

a

6

a

il

"1

(n)

..............

"1

"1

b......... of

..........." "4

“ Ebony Irory edges, Rollers graduated, $12 \mathrm{in}$. long, “

enel $\$ 435$

STEEL CALIPER RULES.

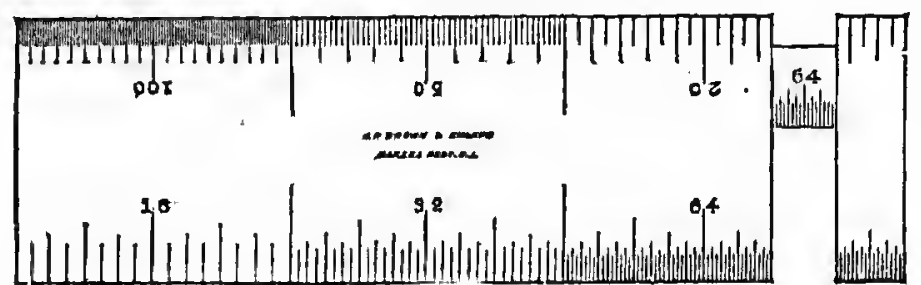

8439 .

The above cut is a fac-simile of one side of these rules. The otwer side is divided into 12 ths, 24 ths, 48ths, 8ths, I4ths, and 28 ths, on the outside, and upon the slide to $32 \mathrm{ds} \& 64$ ths of inches. When closed they are 3 inches long. The enliper can be drawn out to measure two and a half inches. The thickness of the ruse is one-tenth of an inch. The advantages elaimed are their superior eccuracy and durability, price,...........

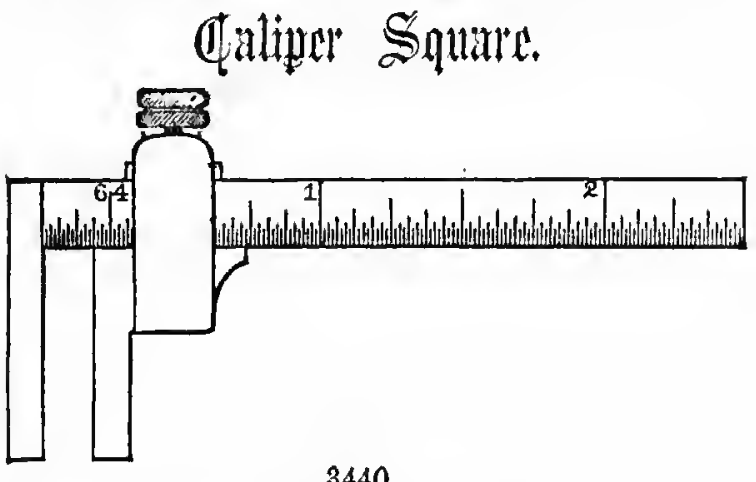

3440.

3440. Caliper Square, 2 inches long 


\section{Bermire Gadiper.}

PRONT BIDE.

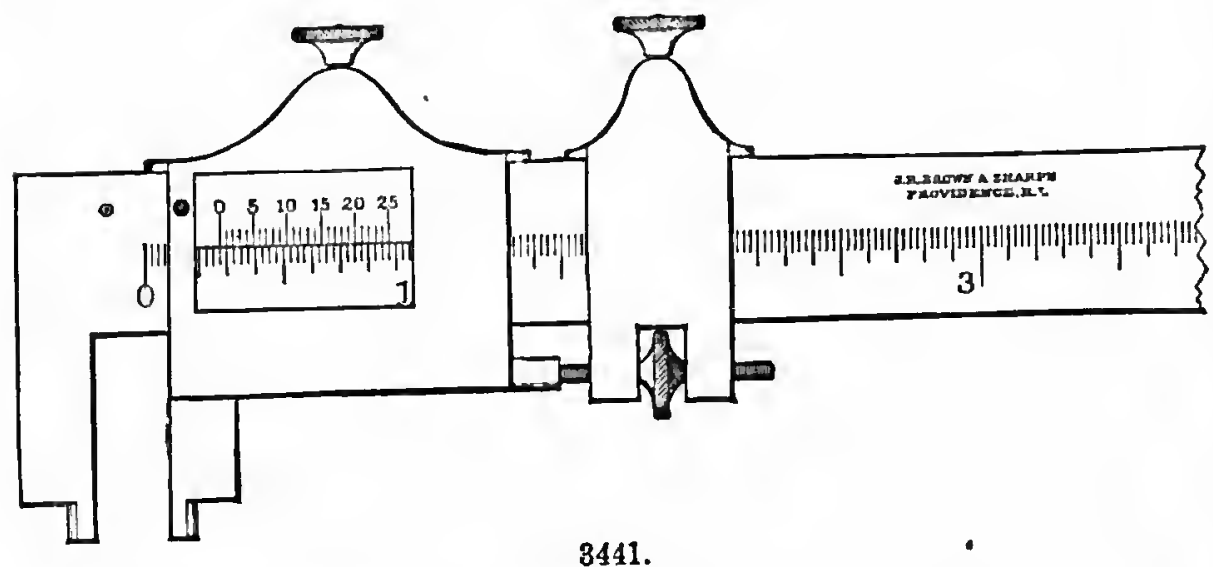

No.

Price.

3441. Vernier Caliper, 6 inches long. The ahore cut is a fac-simile of one side of the Vernier Caliper, which reals to thousandths of inches. The other side reads to $50 \mathrm{th}$ and $6+t \mathrm{th}$ of an inch, without a Vernier. This instrument is furnished with both inside and outside Calipers, and points, to tranefer the distance with dividers. An explanation accompanies cach instrument. Thcse instruments are made of steel, and have the points tempered, in Morocco Box

BACK SIDE.

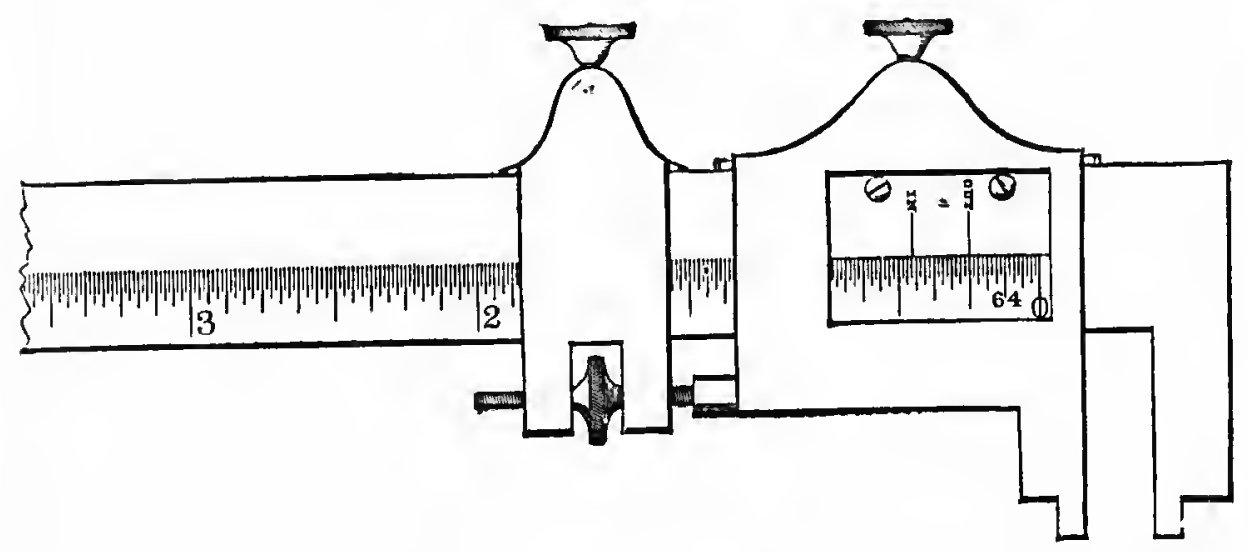

3441.

3442. Vernier Caliper, 12 inches long, same as 3441 , in MLorocco Box, 


\section{Gombination Glunometer \&illte.}

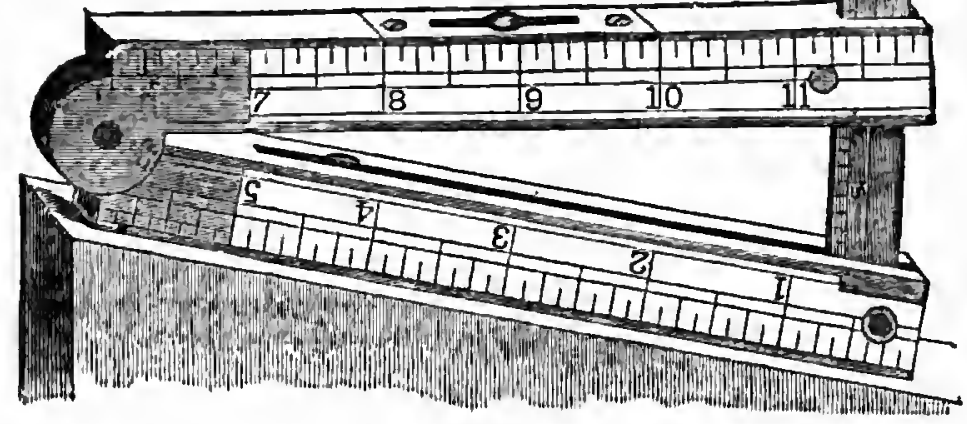

3443.

No.

3443. Combination Clynometer Rule; being the very best form of Slope Level yel invented. It combines within itself-Slope Level for Miners, Carpenters' Rule, Spirit Level. Square, Plumb, Bevel Indieator, Brace Senle, Draughting Scale of equal parts, T Square, Protractor Right Angle Triangle-and with a st raight edge ean be used as a Parallel Ruler, all the parts of which in their eeparate application are perfectly reliable. One foottwo fold. Boxwood.

3444. Combination Rule, Ivory. One font-two fold-same sa above...

A Book giving directions and explanations, for using the Rule, aceompany each Rule.

3445. Engineer's Slide Rule. Boxwood, 24 inches long-two fold,

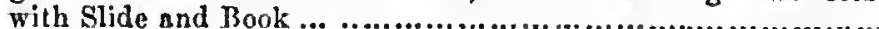

3446. Boxwood Rule, 1 foot, 4 fold, - - divided to 8 th and 16 th,

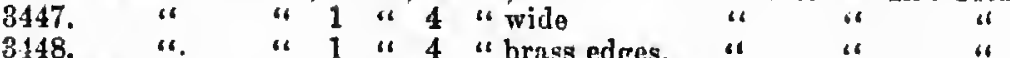

3449. Irory

3450 .

4

8461.

11

8452.

3458 .

"

" 1 " 4 "German Silver monnted "

" 1 " 1 " 4 " "brass edres,

"German Silver edges,

Boxwood

" 1 "

3454.

"1

" 2 " 4 "brass mounted,

" brass edges,

6

5455 .

Irory

$3+56$.

$\therefore$

" 2 "

"

34.57. Boxwood

" 2 " 4

3458. Irory

"German Silver mounted " 


\section{Surveuing}

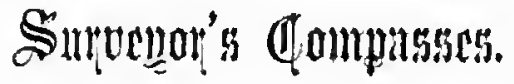

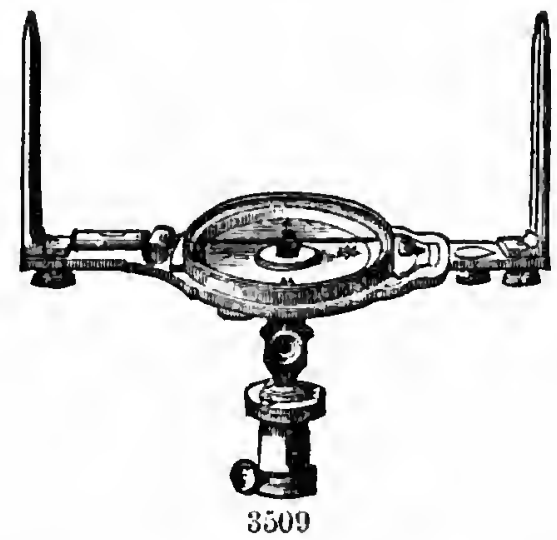

No.

3500. Surveyor's Compass, 4 inch ncedle, 10 ineh plate, 1 straight level, ball and socket,.......................................................

3501. Surveyor's Compass, $4 \frac{1}{2}$ inch necdle, 12 inch plates, 1 straight level and out-keeper, with cover.

Pricz.

3502. Surreyor's Compass, 5 inch needle, 14 ineh plate, circular level and out-keeper, ring divided to half degrees, with eover

3503. Surveyor's Compass, 5 inch neelle, 14 inch plate, cirenlar level, nonius and outkeeper, ring divided to half degrees, with cover,

3504. Surveyor's Compass, $5 \frac{1}{2}$ inch neetle, 15 inch plate, circnlar level and outkeeper, ring divided to half degrces, with cover,

3505. Surveyor's Compass, $5 \frac{1}{2}$ inch needle, 15 inch plate, circular level, nonius and outkeeper, ring clivided to half degrees, with eover,

3506. Surveyor's Compass, 6 ineh needle, 16 inch plate, circular level and outkceper, ring divided to half degrees, with cover,.........

3507. Surveyor's Compass, 6 inch needle, 16 inch plate, circular level, outkeeper and nonius, ring divided to half degrees, with cover,

The above Compasses are all made by $\mathrm{Wm}$. J. Foung \& Co., and are each furnished with a ball and socket, and a neat wooden box.

3509. Surveyor's Compiss, 5 inch ncedle, 15 inch plate, 2 straight levels nonius and outkeeper, ball and socket,

3510. Surveyor's Compass, 6 inch needle, 16 inch plate, 2 straight levels, nonius and outkeeper, and ball and socket, 


\section{Guninere's and Suntewor's Transit.}

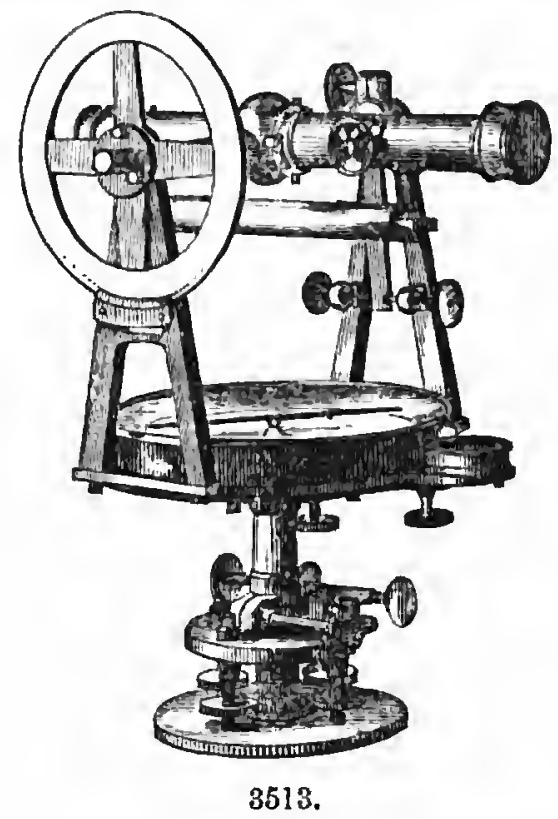

No.

Price.

3512. Transit, plain, eircular plate, tnngent movement, 2 straight. levels, outside rernier, 10 inch teleseope, rack and pinion, movable tripod, $4 t$ ineh needle,................................................

3513. Transit, levcl to telescope, are, poising serews and clamp, $4 \frac{1}{2}$ inch
needle, movable reading glass to veruier, tangent movcment, elamp and leveling screws to tripod liead, with tripod. Transit is paeked in a nent wooden box, with leather strap and handle.

3514. Transit, samo as No. 3612 ; but has 5 inch needle to compass,.....

3515. Transit, samo as No. 3513 ; but has 5 inch needlo to eompass,.....

Each of the Transitg have Young's patent tripod hend, by whieh the Instrument ean readily be moved directly over the point, after being approximately set by the legs.

The above Transits are made by Wm. J. Young \& Co., and aro warranted. They are sold at manufacturers' priees.

- 3518. Jaeob Staff,...

250

3519. Compass Tripod

809

3520. Ball and soeket, without Tangent Serew, ...........................

8521. " " with " "

3522. Marking Pins, per set of 11,

600

1500

165 


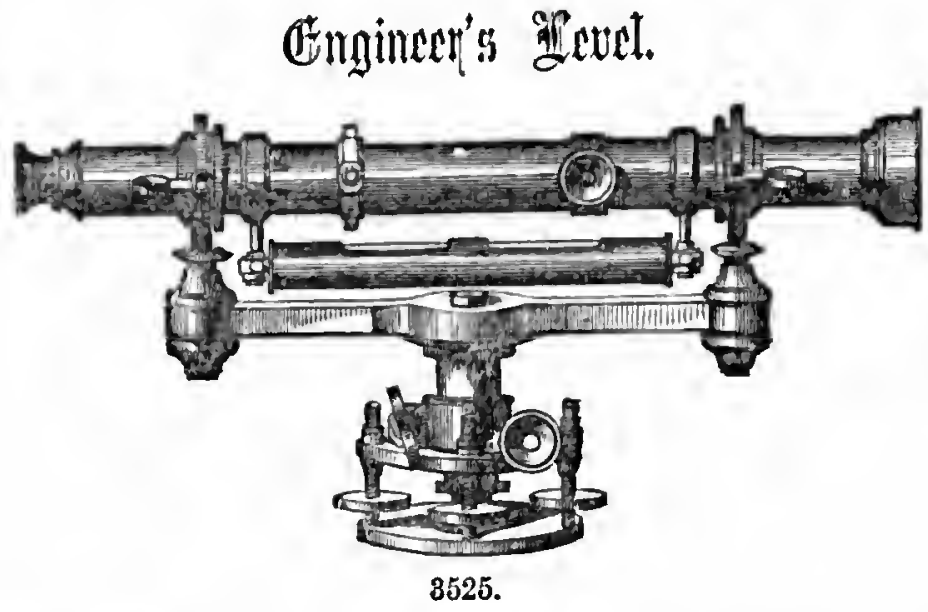

Price.

No.

8525. $\Lambda$ geventecn inch $\Psi$ Level, of the very best construction, made by Wm. J. Young \& Co. Kack and pinion adjustment to object glass, adjustment to eye piece. Clamp and tangent movement;

4 leveling screws, with Tripod...................................... \$140 00

3526. Leveling Rod.

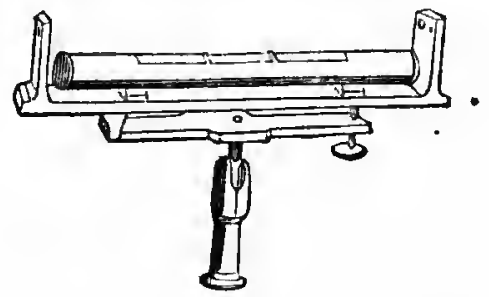

3527.

3527. Level, brass mounted, plate 12 inches long, with sights, and ball and socket joint, in wood case.

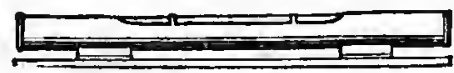

3528.

3528. Levels, Brass mounted, 3 to 12 inches long, per inch.................. 3529. Levels, Brass mounted, with adjustment, 3 to 12 inches long, per inch .................................................................

3530. Levcl Bulbs, unmounted, 2 to 6 inches long......................... 12 to 50 3531. Level Bulbs, unmounted, ground, 2 to 6 inehes long............\$1 00 to 500 


\section{Ietcets.}

\section{SLOPE LEVELS.}

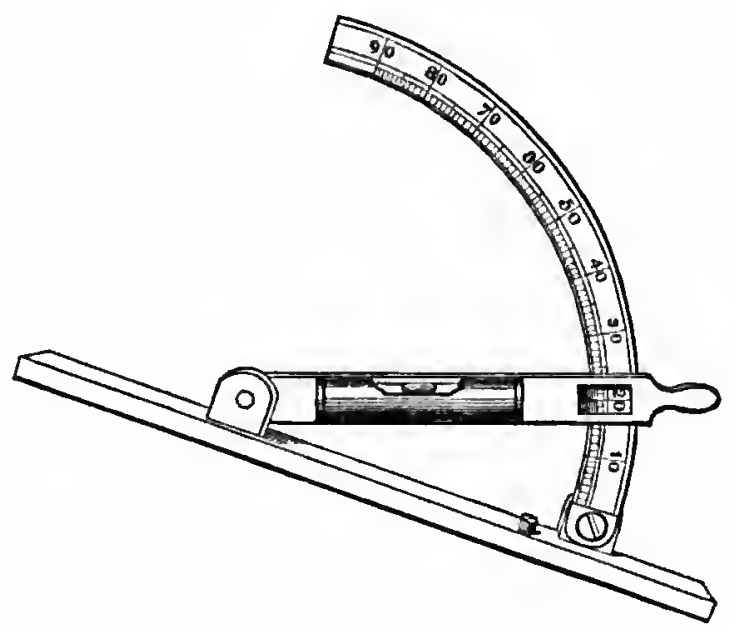

3535.

No.

$\cdot$

Price.

3535. Slope Level, or Clynometer, base $8 \frac{1}{2}$ inches long, in a neat wooden box, for Engineers.................................................... 2536. Slope Level, or Clynometer Square, for Miners, in a neat wooden box.................................................................

3536 . Slope Level, 6 inches long, of brass, with sights and arc, to give the angle of elevation. Ball and socket joint....................
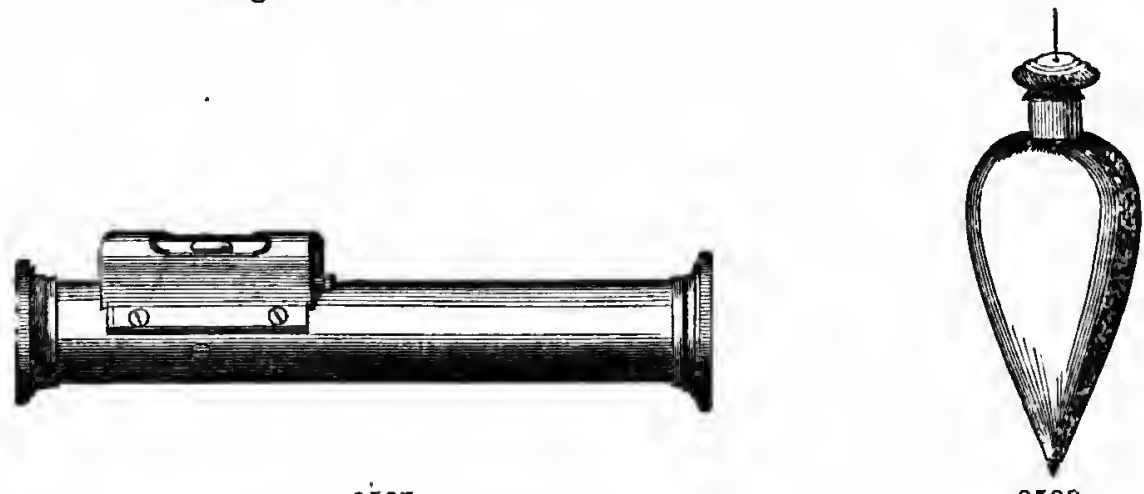

3537.

3539.

3537. Locke's Hand Level, made of German Silver.

1200

3538.

3539. Plumb Bobs, bronze, with serew cap and steel point

$\begin{array}{llll}8540 . & \text { " " " } \\ 3541 . & \text { " } & \text { " without " " " " }\end{array}$

1000

250

".

"6

200 


\section{Survenor's Glaints.}

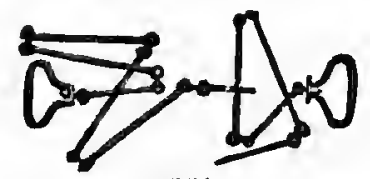

3550 .

No.

3550. Surreying Chain, 2 pole, 50 links, No. 7 Wire.

Prica.

$\$ 325$

200

160

500

400

330

575

525

1100

725

625

550

8562.

8563

16

" 100 " 100 "

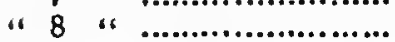

.6 96

\section{Tline gitleasurts.}

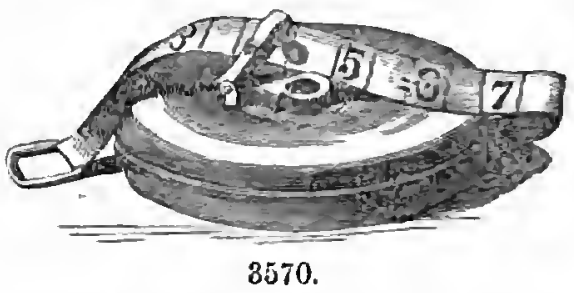

CHESTERMAN'S STEEL TAPE MEASURE.

All Steel, in Lenther Cases, the most aceurate, Durable, and Portable Measure.

35̄65. Steel Tape Measure, 100 feet long, in 10 ths or 12 ths, each... .... \$ 2250

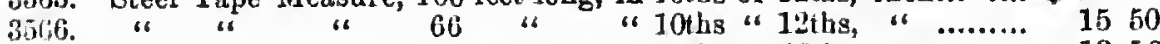

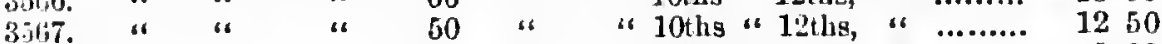

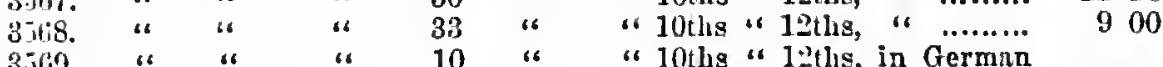

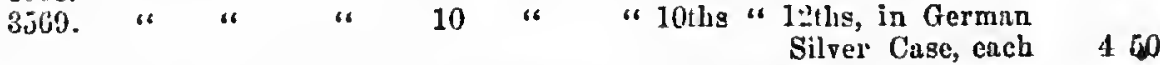

\section{CHESTERMAN'S METALLIC TAPE MEASURES.}

In Leather Cases, made of Linen Thrend, interwoven with Fine Brass Wire, not so liable to stretch as the usual Linen Tape, nnd better enleulated to withstaud the effect of moisture. The best and finest artiele for general use.

3570 . Metallie Tape Neasure, 100 feet long, in 10ths or 12ths, each..... \$ 675

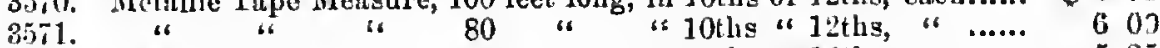

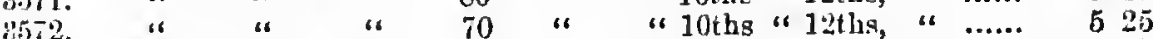

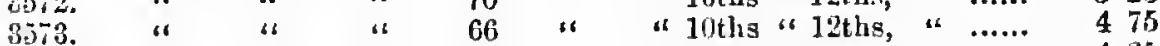

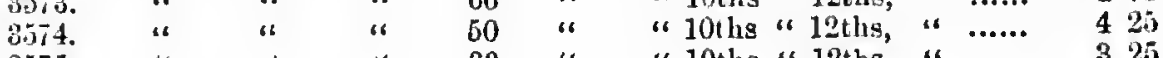

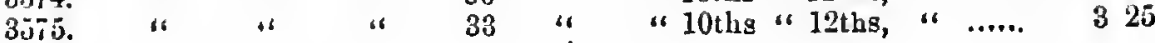




\section{POCKET TAPF MEASURES.}

No.

Prico,

3576. Pocket Tape Measures, all steel, in German silver eases, with spring and stop, 6 feet, 10 ths or 12ths, each..........................

3577. Pocket Tape Measures, all steel, in German silver cases, with spring and stop, 3 feet, 10 ths or 12 ths, ench........................

3578. Pocket Tape Measure, linen, in silver plated cases, with spring and stop, 6 feet, ench.............................................

3579. Pocket Tape Measure, linen, in silver plated cases, with spring and stop, 3 feet, each................................................

3580. Pocket Tape Measure, linen, în brass cases, with spring and brass, 6 feet each..................................................

3581. Pocket Tape Neasure, linen, in brass cases, with spring and brass, 3 feet each......................................................

\section{fochligt $\mathbb{Q}$ oumpasses.}

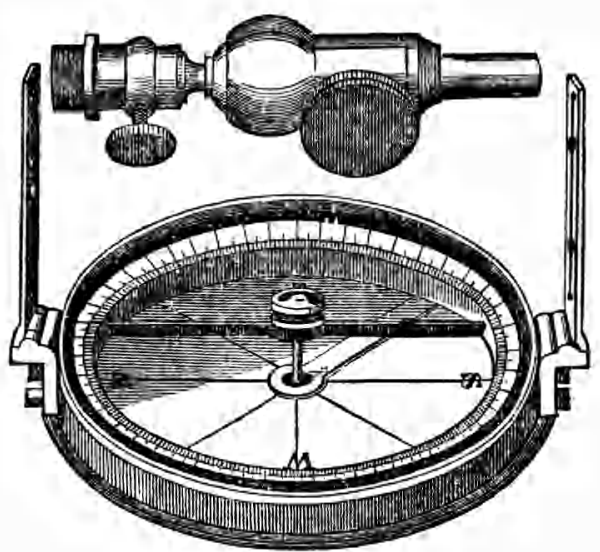

3582.

3582. Compasses of Brass, $2 \frac{1}{2}$ inches diameter, divided to degrees, with sights, and ball and socket joints, in neat morocco cases, each, \$12 00

3583. Compasses of Brass, $3 \frac{1}{2}$ inches in Diameter,....................... 14 00

A very useful pocket Instrument for the Engineer or Surveyor, in making rough surveys.

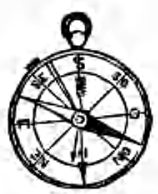

3593.

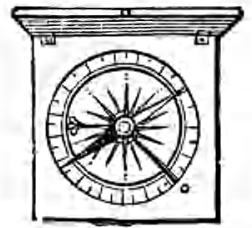

3588 .

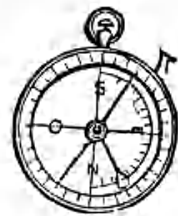

3584.

8584. Geological Compass of brass, with pendulum for ascertaining the angle of dip in rocks, 3 inches diameter, in morocco cases,..... 
No.

3385.

8586 .

$\$ 587$.

8.588.

3589.

8590.

3501.

3592.

3.593.

8594 .

8595.

3596.

3597 .

3598

3590

3600 .

3601.

Pocket Compass,

$\begin{array}{lll}" 1 & \text { "1 } & \text { ruart, } \\ \text { " } & \text { "1 } & \text { mahog }\end{array}$

6611

16 (16

11 16

182

11 16

a

66

ir

16

Prire.

$\$ 1150$

40

25

] 90

225

275

300

50

100

1 గ10

175

100

"with cover, and stop to needle............. Compass, briss, round wilh cover, agate centre and stop to necdle, a very superior instrument.

patlern 11 inches in diameter. contre and stop to needle, enamelled dial $1 \frac{1}{2}$ inches in diameter. ocket Compass, brass, watch pnttern, with hinged cover, agate ccntre, and stop to ncedle, enamelled dial, 2 inches in diameter. centre, and st op to needle, enamelled dial, $2 \frac{1}{2}$ inches in diameter. centre, and st op to needle, enamelled dis inches diameter, agate centre, and stop to needle, with transparent dial, in moroeeo case.

\section{HUNTER'S PATENT DAY AND NIGHT COMPASSES.}

8602. Pockct Compas:, brass, with cover, with paper dial, one-half of which is black, and the other half white, so that a person can see which is North without a light..................................

3603. Poeket Compass, brass, with cover and handlc, with paper dial...

3604. Pocket Compass, brass, with cover and stop, with paper dial......

3605. Pocket Compass, briss, with cover, 2 stops and mother of pearl dial...............................................................

3606. Charm Compnszes, gilt, to linng on watch guard, ench................

8607. " " solid gold........................................ 


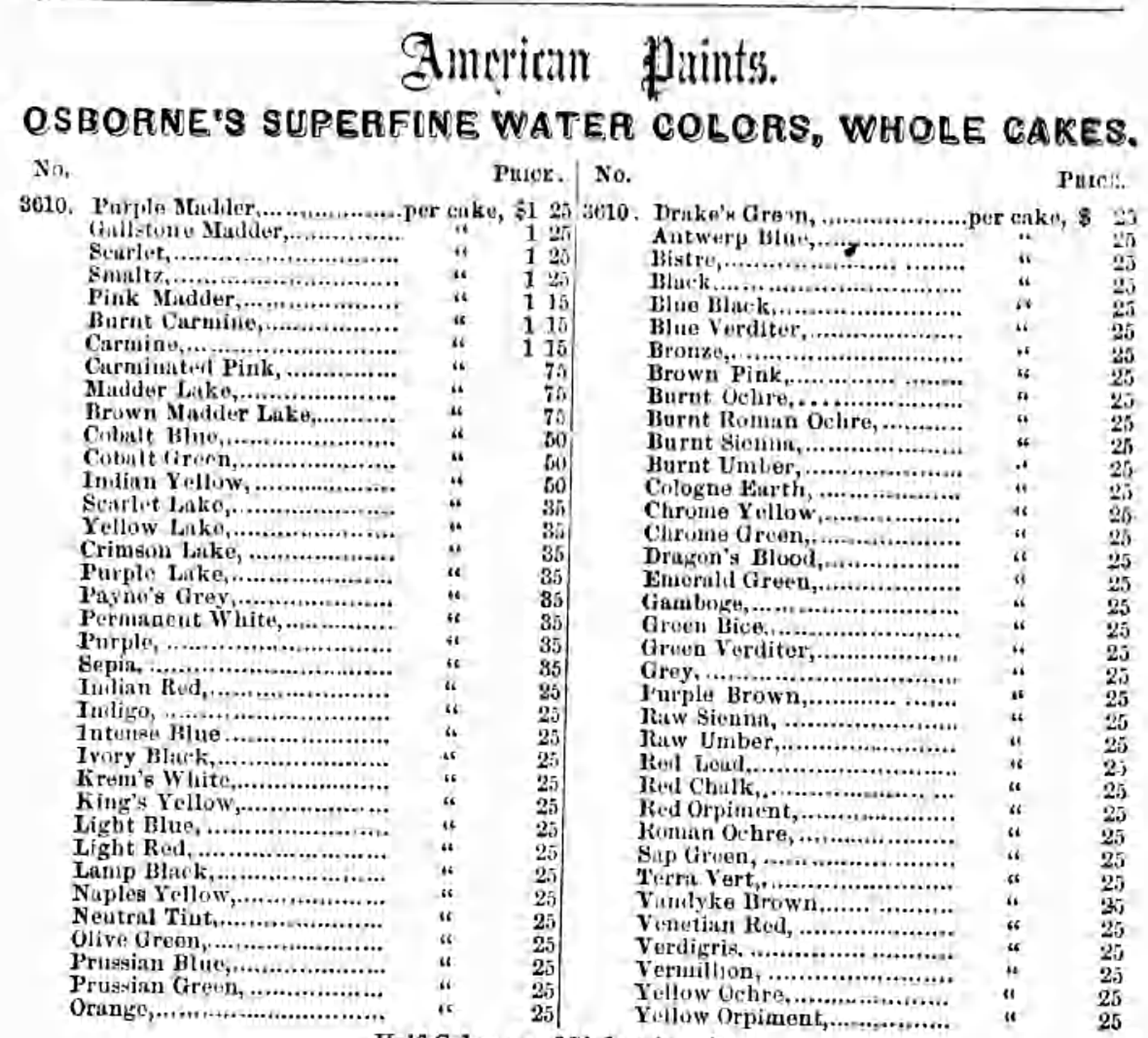

Half Cakes one-fifth less in price.

\section{OSBORN'S WATER COLORS IN BOXES.}

No. Neat Wralnut Boxes, with sliding tops, paint eupi, crayon holder and bruehes.

3611. Wulnut Box, 6 rows, containing 30 colors, brushes, ets

3612.

3013.

$3 i 14$.

$3 \mathrm{t} 15$,

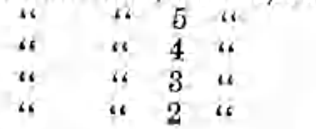$$
\begin{array}{lll}
* & 25 & 6 \\
* & 20 & 4 \\
* & 15 & 4
\end{array}
$$

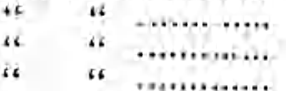

\section{HALF SIZE.}

3616. Walnut Box, 6 rows, containing 80 colors, bushes, etc.

3617 .

Silis.

3619 .

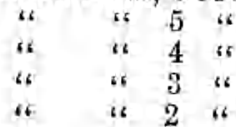

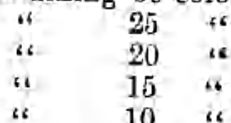

$a$
$a$
6

Ilandsome Muhogany and Rosewnod Clreste.

3622. Mahogany Chest, fitted with lock and drawer, paint stone, water glass, india ink, brusheg, crayon holder, rests, etc, with 12 colors.

3693. Rosewood Chest, fitted with loek and drawer, paint stone, wnter glass, indis ink, brushes, crayon holder, rests, otc., with 18 colove.

3624. Rosewood Chest, fitied with lock and drawei, pint stone, water glass, india ink, brushes, crayon loolder, rests, etc., with 24 colors. 


\section{WINDSOR AND NEWTON'S WATEB OOLORS.}

No.

Pricg. No.

Pricr.

3uro. Burnt Carmine,................. per cake, \$2 25

Cultuium Yellow,

Caduiutn Ora uge, ................

Curmine",

Gillstone

Mfudilor Carmilne,..................

A ursullue,

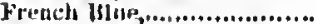

(irewis bxilte of Clirome......

Jufuse Bluc,

$\begin{array}{lll}* & 425 \\ 14 & 2 & 25 \\ 4 & 2 & 25 \\ 4 & 2 & 25 \\ 4 & 2 & 45\end{array}$

3626. Mara' Orange,

Mara Orange,......................per caka, $\$ 2$ 25

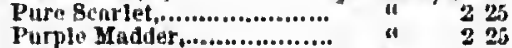

Smalt............................. " 225

Ultramuilut A\&b,............. u 225

Inalf cules, 8110 .

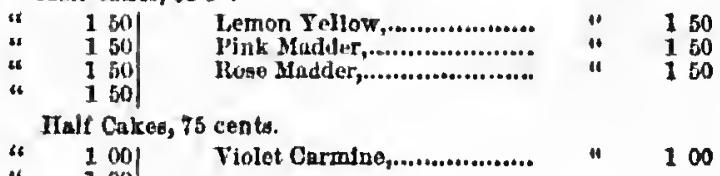

Cotmit Rlua, ......................

Orunge Vermillion,

Jirowu Muillar,

C hinman Whitu",

Cunstant Whits.

C'rintaril Lilken.

Indlinn Villow,

Murs Folluw.....

Antwern Blue,

IBintri.....

(t)

iu'k

Jiritislı Iuk,.....................

lireswit (k-hire

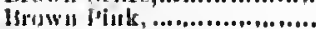

Rurnt Rumait O:lir............

Hurnt dientuk,.... ..................

Burnt Ember.

Clircine Yellow

In'en Clorome.

Itritruis't Blinis!

Einerala orroen

Fluk! White,

Craunbroga,

llonker's hemp No............

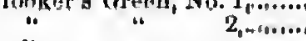

Indlugo,

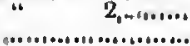

Indiatu 13 end,

Italuan Pink

I vory BIuck.

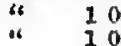

IIalf Cakes, 50 cents,

\begin{tabular}{|c|c|c|c|}
\hline “ & $\sin 1$ & Purthlo Inko, ....................... & 4 \\
\hline औ & 80 & Itonun Bepia,..................... & $" 1$ \\
\hline 16 & 80 & Kubrn's Miudder,.................. & $" 1$ \\
\hline Cf & 80 & Suarlet Lake,....................... & 4 \\
\hline & 80 & Bcarlut Vermllllon,.............. & $\omega$ \\
\hline & 80 & Stplat,................................., & " \\
\hline & 80 & Wurm Bupin, ..............., , ., , . & " \\
\hline
\end{tabular}

\section{Half Cak' 40 cents.}

\begin{tabular}{|c|c|c|c|c|}
\hline$a$ & 40 & Kinr's Yellow,.................... & a & 40 \\
\hline 4 & 40 & Lamp Black,......................, & a & 40 \\
\hline "4 & 40 & 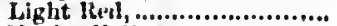 & a & 40 \\
\hline I6 & 40 & Naples Yollow,.................. & 6 & 40 \\
\hline 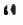 & 40 & Nentral Tint,.................... & os & 10 \\
\hline " & 40 & Olive Green,....................... & " & 40 \\
\hline "6 & 40 & Orange Chrome, ................ & "6 & 40 \\
\hline " & 40 & Payno's Groy, ..................... & $60^{\circ}$ & \\
\hline "4 & 40 & Prussian Bluo, ,................. & " & \\
\hline " & 40 & Prusgian Green, ................... & " & \\
\hline 6 & 40 & Rnw Siennn,...................... & "1 & 40 \\
\hline " & 40 & Itu w Umber, ........................... & (4) & \\
\hline ct & 40 & Red Lend,............................ & "w & \\
\hline " & 4) & Rrumnn Ochre,..................... & 6 & \\
\hline " & 40 & Sil p Green, & it & \\
\hline " & 4) & Tarra Vert,......................... & * & \\
\hline " & 40 & Vundyke Jrown,............... & " & \\
\hline " & 40 & Venotlan Red,...................... & ti & \\
\hline 4 & 40 & Virmillion, & "l & \\
\hline 11 & 40 & Yellow Lnko,..................... & +1 & \\
\hline is & 40 & Yallow Ocbro,....................... & " & \\
\hline
\end{tabular}

Half Cakes, as centa.

No.

3600. A. W, Faber's superior Siberian Lend Peneils, B. IIB. \& H., eneh aj cents, per dozen.

3651. A, W. Fuher's Herngonal, Gili, Nos. $1,2,3,4$, eneh 15 eents, per

8652. A. W. Fiber's black, roumd nnd gilt, Nos. $1,2,3,4$, ench 10 cents, per dozen............................................................

3653. A, W. F'nber's hlack, rousd and gilt Union, Nos. $1,2,3,4$, each 7 cents, pur dozen.

36.54. A. W, Fubor's blaek, round and gilt, Star, Nos. 1, 2, 3, 4, each 6 cents, per dozen.

3955. A. W. Faber"s Polygrades in boses, 7 in each box, per box...........

2057. Eagle Pencils, 7 in eneh box, per box. 
::6:8, Sinnll Lead Penoils for Dividerg, each 5 cents, per dozcn........... 50

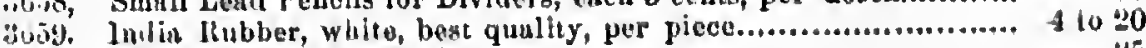

intive Indis Rubber and Ink Erasers.................................... 20

3:61. India Ink, good article.................................................. 15 to 30

siti2. " "be日t " ........................... " ......... 30 to 100

¿́ces " " puro " small cako, $\$ 100$ cach, largo............... 800

stitit. Mouth Glue, per piece................................................... 05

3665, Gillotl's Ilapping Pen's, per dozen.. .............................. 80

31360. “ Lithograph Crow Quill, on cards per dozen ............... 100

30ist. Erasing kuives, cuch................................................ 60 to 75

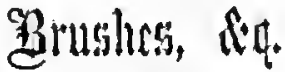

3:68. Camel's Hair Pencils, common, per dozen......................... 15

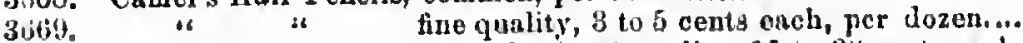

3670 . Sable, " in quills, tiuest quality, 16 to 30 conts ench, per dozen..................................................................

3471. Comel's Il air Pencils with polished handles, assorted, each......... o to 20 sút2. Sable " " " " " " "..... 20 to 50

\section{gaint Sillubs and Saucers.}

\section{PORCELAIN SLAES}

For India Ink and Colors. Containing three Moles or Cups and one Slanting Division.

36i3. Porcelain Slab, $1 \frac{1}{2} \times 2 \%$ inches, cach.................................... 20

$3674 . \quad$ " " $2, \times 4$ inches, earh................................ 40

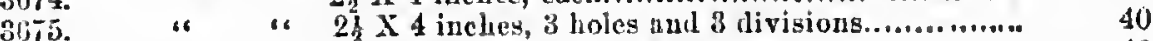

$\$ 676 . \quad$ " $\quad$ " $2 \mathrm{X} 4 \mathrm{inches,} 3$ divisions, best...................... 40

\section{Dortclain Sinteres in êlests.}

3077 3678. 3679 .

Containing 6 Saucers 2 inches dimmeter, per nest.

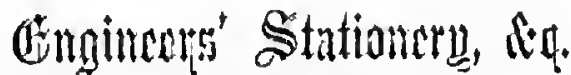

\section{WHATMAN'S TURKEY MIIU DRAWING PAPER.}

3C80. Demy,

3681. Medium,

3682. Royal,

8663. Super Royal,

3684. Elephant,

3685. Imperial,

8486. Columbier,

3687. Atlas,

Atlas, $\quad 33 \times 26$

3689 . Antiquarian, $52 \times 31$

$24 \times 19$

$30 \times 21$

$34 \times 23$
$20 \times 15$ inches, per shcet 9 cents, per quire,... $22 \times 17$

$27 \times 19$

$28 \times 22$

6
6
16
16
6
6
46
6

150

200

300

350

550

560

600

600

800

3000 


\section{INGINEERS' DRAWING PAPER IN ROLLS.}

Very Sirong, for Architcets, Engineers, \&c., \&c.

3\%50. White, extra thick, 40 inelies wide, in rolls, per yard,..............

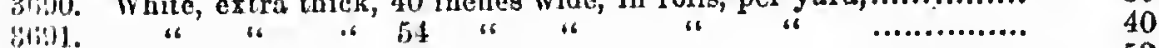

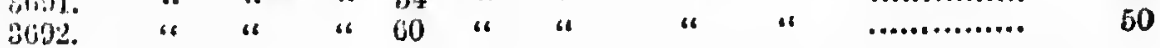

\section{DRAWING PAPER ON MUSLIN.}

3603. In rolls 8 yards long, and 40 inches wide, per yard,.................

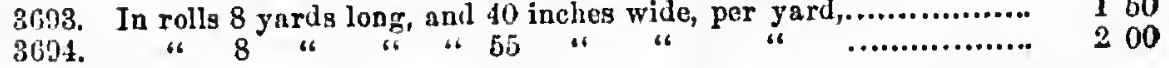

\section{FRENCH TRACING PAPER.}

Very fine quality, very clear and sirong.

3695. In sheets. Royal, $19 \times 25$ inclies, per sheet, 12 eents, per quire, 3696.

$3 \mathrm{ij} 9 \mathrm{i}$.

$3+59$. In rolls 11 yards long and 43 inehes wide, per yard, ................. " Super Royal, $21 \times 26$

“ Double Elephant, $28 \times 40$ “

15 "

\section{TRACING OR VELLUM CIOTH.}

Saeger's Patent, Transparent, in Rolls.

3700 . In rolls 16 inches wide and 24 yards long, per yard,................

3701. " 36 " " " 24 " "

\section{PATTERN PAPER.}

Buff Tint, very Strong and Thick.

3702. Double Thick, 36 inches, wide, in rolls, per yard,................... 8708 " " 44 " " "

\section{PROFILE AND CROSS-SECTION PAPER.}

3704. Profile Paper, A, ruling $43 \times 17$ inehes, horizontal ruling, 20 to the ineh, per sheet,...................................................

3705. Profile paper, $B$, ruling $43 \times 17$ inclies, horizontal ruling 30 to the inch, per sheet, ..............................................

;iof. Cross-Section Paper, $23 \times 18$ inehes, 8 feet to ineh, per sheet,....

:ivuT. Trautwine's Cross-Seetion and Diagram Paper, 10 feet to inch, for embankments of 14 and 24 feet roadway, and for excavations of 18 and 28 feet; ruling $19 \frac{3}{4} \times 12$ inehes, per sheet,............ 


\section{Afllistellameous.}

- STANDARD WIRE GAUGES.

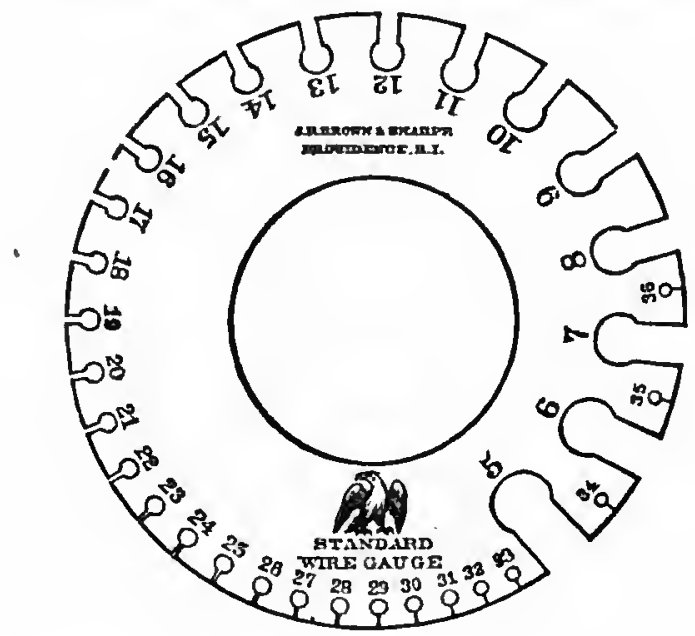

No.

3710. Round Gauges, sizes 0 to 36 ,

Price.

CENTRE GAUGPS.

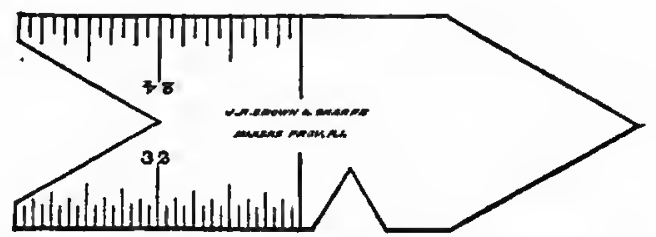

3712. Centre Gauge, same size as cut, made of steel, for machinists,.....

\section{WILLIS' ODONTOGRAPH.}

3713. This is an instmment recently invented by Prof. $R$. Willis, of Cambridge University, England, for describing the corrcet form of the teeth of whecls, and the templets and cutters used in making them. All wheels of the anme pitch, but of different sizes, having their tecth drawn with this instrument, will run together correctly. No. 1 is used for drawing the tecth of small whecls by diametrical pitel when only a single are is required. Price, \$3 50, with drawings and directions for use. No. 2 is for drawing the teeth of larger whecls by circular pitch, where it is necessary to have separate arcs for flanks and faces.Price, \$3 50, with drawings and dircetions for use. Price per pair, 


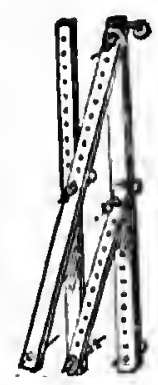

PENTAGRAPHS,

No.

3714. Pentagraph made of walnut, for enlarging and reducing drawings, 8715. Plnin steel Calipers for outside measure, with adjusting serew.Measure to 101 inches,............................................

3716. Plain steel Calipers for outside measure, with ndjusting serew.Measure to 7 inehes,.................................................

3717. Plain steel Calipers for outside measure, with adjusting screw.Measure to $3 \frac{1}{\text { inches, }}$...

3718. Stecl Dividers, 8 inch, with are, clnmp serew and adjusting serew, 3710. Steel Dividers, 6 inch, with are,'elamp serew, and udjusting serew 3720. Steel Self-Registering Dividers, with elamp serew and nijusting legs, so that the points may always be kept true. Register to 3 inches. A new and very complete inst rument,..................

3721. Self-liegistering Calipers for outside measure, with clamp screw.

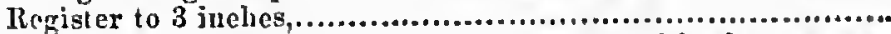

3722. Sclf-Registering Calipers for outside measure, with elamp screw. Register to 2 inelies, ...............................................

9723. Self-Registering Calipers, for outside measure, register to 2 inches, 3724. Self-Registering Calipers, for outside measure, register to 11 inches,

3725. Self-Registering Calipers for inside measure, with elamp screw,

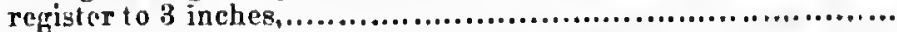

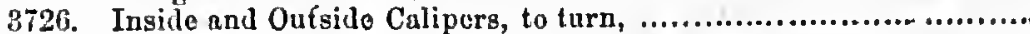

$3727 . " 6 "$ " $"$ in one piece,............................
Price.

$\$ 450$

100

100

100

150

\section{MAGNIFYING GLASSES}

For Reading Verniers, \&ce, \&c.

3728 India Rubber 1 lens,

3729.

$37: 0$.

3731.

3732 .

3732.

\begin{tabular}{|c|c|}
\hline "6 & " \\
\hline if & $" 6$ \\
\hline \& & " \\
\hline "6 & $" 4$ \\
\hline
\end{tabular}

$\frac{1}{2}$ ineh diameter,

Any other articles, not enumerated in the catalogue, will bo furnished at the lowest price, and on the shortest notice. 


\section{3ookts.}

8740. Level Books, ..............................................each,

3741. Transit Books, .....................................each,

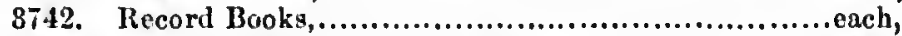

3743. Gillespie's Land Surveying,...........................each,

3744. Gillespie's Manual of Road-Making,....................ench,

3i45. Heather's Treatise on Mathematical Instruments,...each,

3746. Ilaupt's Bridge Construction, ..........................each,

3747. Minifie's Geomotrical Drawing,........................each,

3748. Warren's Draughtsman's Manual, .......................each,

3719. Warren's Draughtsman's Instruments,.................cach,

3750. Warrcn's Linear Perspective, .........................each,

3751. Nystrom's Pocket Book of Mechanics and Engi-

neering, ..............................................each,

3752. Praotical Surveyor's Companion, by E. W. Bean's, each,

3753. Treatise on tho Slide-Rule; being a guide to the Engineer, Gauger, Soannan and Student, by Thomas Kentish; illustrated by numorous engravings, .............................................each,

3754. Trautwine on Railroad Curves. The Field Practice for laying out circular curves for railroads,......each,

3755. Trautwine on Excavations and Embankments. A new method of calculating the cubio contents of excarations and cmbankments by tho aid of dia-

grams, .................................................each,

Price. Poutage.

75

125

400

200

60

400

150

125

100

150

250

75

125

200

200
12

4

36

20

8

28

1.

12

12

16

8

8

12 